\title{
Phylogenetic relationships within Schminkepinellidae fam. $n$., a new monophyletic group of marine cyclopinids (Cyclopoida: Copepoda), description of two new genera and four new species
}

\author{
Pedro Martínez Arbizu \\ DZMB - Forschungsinstitut Senckenberg, Südstrand 44, 26382 Wilhelmshaven, \\ Germany. \\ e-mail: pmartinez@senckenberg.de
}

\begin{abstract}
The new family Schminkepinellidae fam.n. includes five genera: three known ones: Muceddina Jaume et Boxshall, 1996, Barathicola Humes, 1999, and Cyclopinella, Sars 1913, and 2 new genera:Einslepinella gen.n. and Schminkepinella gen.n. The new monophyletic group is characterised by the absence of a coxal endite on the maxillule, and by the spinal condition of the distal inner element on the middle endopodal segment of leg 4. A phylogenetic analysis shows Muceddina to be the relatively most primitive taxon, followed in sequence by Barathricola, Cyclopinella, Einslepinella gen.n. and Schminkepinella gen.n. It is argued, that at least, species belonging to Einslepinella gen.n. may be loosely associated with invertebrates.
\end{abstract}

KEYWORDS: Schminkepinellidae fam.n., Schminkepinella gen.n., Einslepinella gen.n., Cyclopinidae, Copepoda.

\section{Филогенетические отношения в Schminkepinellidae fam. n. - новой монофилетической группы морских циклопинид (Cyclopoida: Copepoda), описание двух новых родов и четырех новых видов}

\section{Педро Мартинез Арбизу}

\author{
DZMB - Forschungsinstitut Senckenberg, Südstrand 44, 26382 Wilhelmshaven, \\ Germany. \\ e-mail: pmartinez@senckenberg.de
}

РЕЗЮМЕ: Семейство Schminkepinellidae fam.n. включает пять родов: три ранее известные:Muceddina Jaume et Boxshall, 1996, Barathicola Humes, 1999 и Cyclopinella Sars,1913, а также 2 новых рода: Einslepinella gen.n. и Schminkepinella gen.n. Новая монофилетическая группа характеризуется отсутствием коксального эндита максиллул и шиповидной формой дистального внутреннего элемента вооружения на среднем членике эндоподита четвертой плавательной ноги. Филогенетический анализ показывает, что в ряду таксонов рассматриваемой группы, самым примитивным является род Muceddina, за которым следуют роды Barathricola, Cyclopinella, Einslepinella gen.n. и Schminkepinella gen.n. Показано, что виды, принадлежащие, по 
крайней мере, роду Einslepinella gen.n., связаны с другими беспозвоночными слабо выраженными симбиотическими отношениями.

КЛЮЧЕВЫЕ СЛОВА: Schminkepinellidae fam.n., Schminkepinella gen.n., Einslepinella gen.n., Cyclopinidae, Copepoda.

\section{Introduction}

Cyclopoida are, apart from Harpacticoida, one of the most characteristic groups of Copepoda among the marine metazoan meiobenthos. Most species of meiobenthic cyclopoids are epibenthic, although species of some genera have invaded the interstices of sandy beaches. During an extensive study of marine benthic copepod biocenoses in the Arctic Ocean, several species of cyclopinid Cyclopoida were found in hyperbenthic water layers. Surprisingly, cyclopinids were not restricted to shallow waters, as was previously thought, but are regularly present also in abyssal depths. What is even more interesting, Schminkepinella plumifera gen.n., sp.n. was found to be the dominant copepod species in deep waters of the Laptev Sea.

The family Cyclopinidae was proposed by G.O. Sars (1913) for a few known species and those gnathostomous cyclopoids that he had discovered in marine coastal habitats of Norway. Sars included in this family the previously described genera Cyclopina Claus, 1863 and Pterinopsyllus Brady, 1880 and two new genera Cyclopinella Sars, 1913 and Cyclopetta Sars, 1913. The genus Cyclopina was at that time a very heterogeneous assemblage and was split into several genera in subsequent revisions by different authors (Steuer, 1940; Lang, 1946; Lindberg, 1952). Although not explicitly mentioned by Sars, his decision to propose a separate genus for Cyclopinella tumidula may have been due to the presence in this species of several striking characters: i) first pedigerous somite not fused to cephalosome, ii) complete absence of antennal exopod, iii) all 5 setae on third endopodal segment of leg 4 spine-like, iv) mandibulary exopod reduced to a single seta. These characters remained unique among cyclopinids until the discovery of Muceddina multispinosa Jaume et Boxshall, 1996 in anchi- aline caves of Sardinia, the Balearic and Canary Islands (Jaume, Boxshall, 1996) which displays characters i.-iii. Although initially not recognised by the latter authors, the close phylogenetic relationship between Cyclopinella and Muceddina is clear. Barathicola Humes, 1999 known from a deep sea hydrothermal vent site in the northeastern Pacific (Humes, 1999) can be added to this cluster of genera, as well as two new genera viz. Schminkepinella gen.n. and Einslepinella gen.n. described herein.

A revision of Cyclopinidae using the methods of phylogenetic systematics (Hennig, 1982) is underway in order to elucidate the phylogenetic relationships of cyclopinid genera and the cyclopoid families as a whole. As one step a new monophyletic group viz. Schminkepinellidae fam.n. is recognised and defined here.

\section{Material and Methods}

Meiobenthic samples were taken during the German expedition ARK IX/4 (August-October 1993), on board of RV Polarstern using a Multicorer and a Giant Box Corer. All samples were fixed with buffered formalin at a final concentration of $4 \%$. Meiofauna was extracted by differential flotation and centrifugation using Levasil®. Drawings were made using a camera lucida on a Leitz Diaplan interference contrast microscope.

The specimens have been deposited in the Copepod Collection of the AG Zoosystematik und Morphologie, University of Oldenburg, Germany.

The terms "furca" and "telson" are used according to Schminke (1976); terms of phylogenetic systematics are used according to Hennig (1982); the term "groundpattern" is used in the sense of "Grundmuster" (Ax, 1984). The phylogenetic argumentation scheme was made per hand using the so-called „Hennigian Principle" (Meier, 1992; Wägele, 2000). 


\section{Descriptive part}

\section{Ordo Cyclopoida}

\section{Schminkepinellidae fam.n.}

Diagnosis (groundpattern). Cyclopoida, body cyclopiform. Tergite of first pedigerous somite free, and not concealed beneath a carapace-like extension of cephalosome. Antennule 15-segmented in female, and 17-segmented in male. Antenna 4-segmented; coxo-basis with one inner seta, without exopodal setae; endopod 3-segmented with 1, 5 and 7 setae. Mandible with basis bearing 1 seta, 2-segmented endopod with 3 and 6 setae, and 4 segmented exopod with 1, 1, 1, and 2 setae; exopodal segments reduced in size. Maxillulary praecoxal arthrite with 10 armature elements, coxal epipodite represented by 3 setae, coxal endite undeveloped and setae absent. Maxilla with praecoxa bearing 2 endites, proximal one with 3 setae and a small spine, distal endite with one seta; coxa with 2 well developed endites bearing 3 setae each; basis produced into a strong claw flanked by 2 setae, 3 -segmented endopod (proximal segment being a double segment) with 4, 2 and 4 setae. Maxillipedal syncoxa with 5 setae altogether, basis with 2 setae; and endopod 5-segmented with 1, 1, 1, 1 , and 4 setae. Legs 1 to 4 with 3 segmented rami, without inner seta on first exopodal segment. Leg 1 with only 1 inner seta on middle endopodal segment, legs 2 to 4 with 2 armature elements on this segment. Third endopodal segment of leg 3 with both terminal setae transformed into spines. Third endopodal segment of leg 4, all 5 elements spines-like, distal inner seta on middle endopodal segment of this limb also spine-like. Leg 5 with distinct coxa and basis in both sexes; coxa without inner seta, basis with 1 outer seta; exopod 1-segmented with 4 armature elements in female ( 3 spines and 1 terminal seta); 2 segmented in male, with 1 inner seta and 1 outer spine on proximal and 4 elements on distal segment (one inner seta, distally one spine and one seta, and one outer spine). Leg 6 a plate with only 1 well developed seta in female and 3 well developed elements in male. Furca with 7 setae, seta I vestigial, inserting on dorso-lateral margin of furca close to seta II.

Type genus: Schminkepinella gen.n.

Other genera: Cyclopinella Sars, 1913,Muceddina Jaume \& Boxshall, 1996, Barathricola Humes, 1999, and Einslepinella gen.n.

\section{Schminkepinella gen.n.}

Diagnosis (groundpattern). Cyclopoida, Schminkepinellidae. Body cyclopiform. First pedigerous somite free, not covered by a carapace-like extension of the cephalosome. Antennule 8-segmented in female, indistinctly 6-segmented in male. Both sexes in all with 9 antennulary aesthetascs. Antenna 2segmented; first segment with 1 inner seta, second with 9 elements. Mandible with falcate gnathobasis curved inwardly, palp with 1-segmented endopod and exopod. Maxillule reduced, coxa asetose. Maxilliped 2-segmented, feather-like, not prehensile, first segment with 1 seta, second segment with one long and densely bipinnate element. Swimming legs 1 to 4 with 3 -segmented rami. First exopodal segment of legs 14 without inner seta. First leg without outer basal seta, inner spine elongate; second endopodal segment with only one inner seta. Outer margin of first exopodal segment of leg 1 without spinules. Third endopodal segment of legs 1 to 4 without outer element. Third endopodal segment of leg 3 with both terminal setae spine-like. Leg 4 with all 4 setae on third endopodal segment and distal inner seta on second endopodal segment spine-like. Leg 5 with well developed intercoxal sclerite, coxa, and basis; endopod 1-segmented in both sexes. Female genital double-somite subdivided ventrally, with ventro-medial single copulatory pore; seminal receptacles tetralobed; gonopores located laterally, leg 6 with one seta.

Male leg 6 with 3 well developed elements. Furca elongate, with 6 setae; seta I lacking, seta II and III located on dorsal margin.

Type species: Schminkepinella plumifera gen. et sp.n.

Etymology. This genus is dedicated to Prof. Dr. H.K. Schminke (University of Oldenburg) for his enthusiastic dedication in promoting systematic and phylogenetic studies in Germany. The generic name is formed by combination of the name "Schminke" with "pinella" which is part of the name of the closely related genus Cyclopinella Sars, 1913.

\section{Schminkepinella plumifera sp.n.}

Material. Holotype female dissected and mounted on 10 slides (UNIOL 1998.016/1-1998.016/10); allotype male mounted on one slide (UNIOL 1998.017/1); paratype: one female dissected and mounted on 11 slides (UNIOL 1998.018/1-1998.018/11)

Locus typicus. The material was collected the 12 September 1993 at $3211 \mathrm{~m}$ depth in the Laptev Sea $\left(79^{\circ} 12.96^{\prime} \mathrm{N} 122^{\circ} 54.37^{\prime} \mathrm{E}\right)$

Female. Habitus cyclopiform (Fig. 1A-B). Body length (measured from frontal rim of cephalosome to caudal margin of telson) $398 \mu \mathrm{m}$. Urosome without ornamentation. Pseudosomite present between fifth pedigerous somite and genital double-somite (Figs 2C, 6A). Arthrodial membrane separating posterior thoracic and anterior abdominal somites present ventrally, absent dorsally. Single copulatory pore located medially on ventral surface; seminal receptacles comprising 4 distinct chambers (Fig. 2C). Furca 


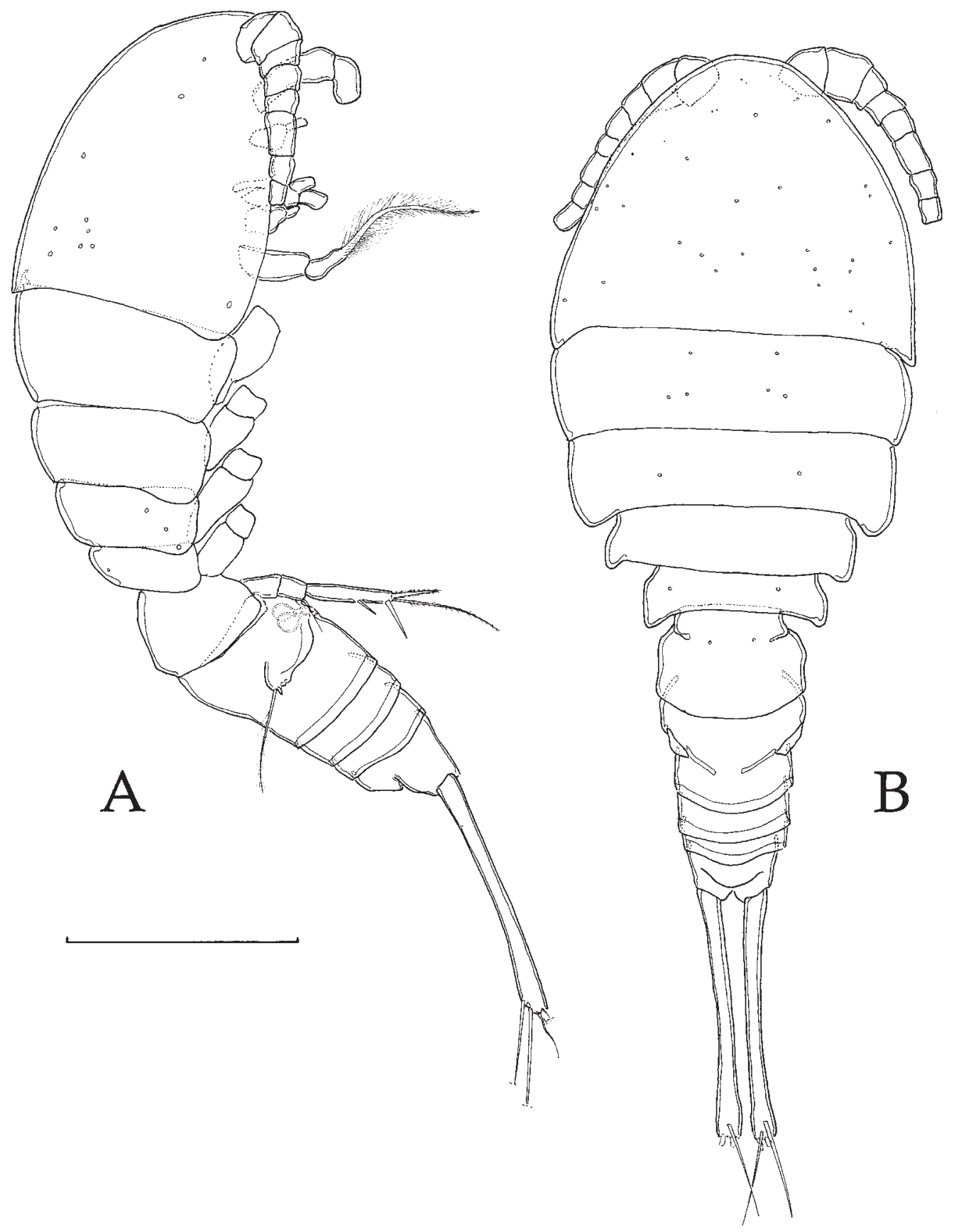

Fig. 1. Schminkepinella plumifera gen.n., sp.n. Habitus of female. A - lateral view; B - dorsal view. Scale bar $100 \mu \mathrm{m}$.

Рис. 1. Schminkepinella plumifera gen.n., sp.n. Общий вид самки. А - вид сбоку; В - вид со спинной стороны. Масштаб 100 мкм. 


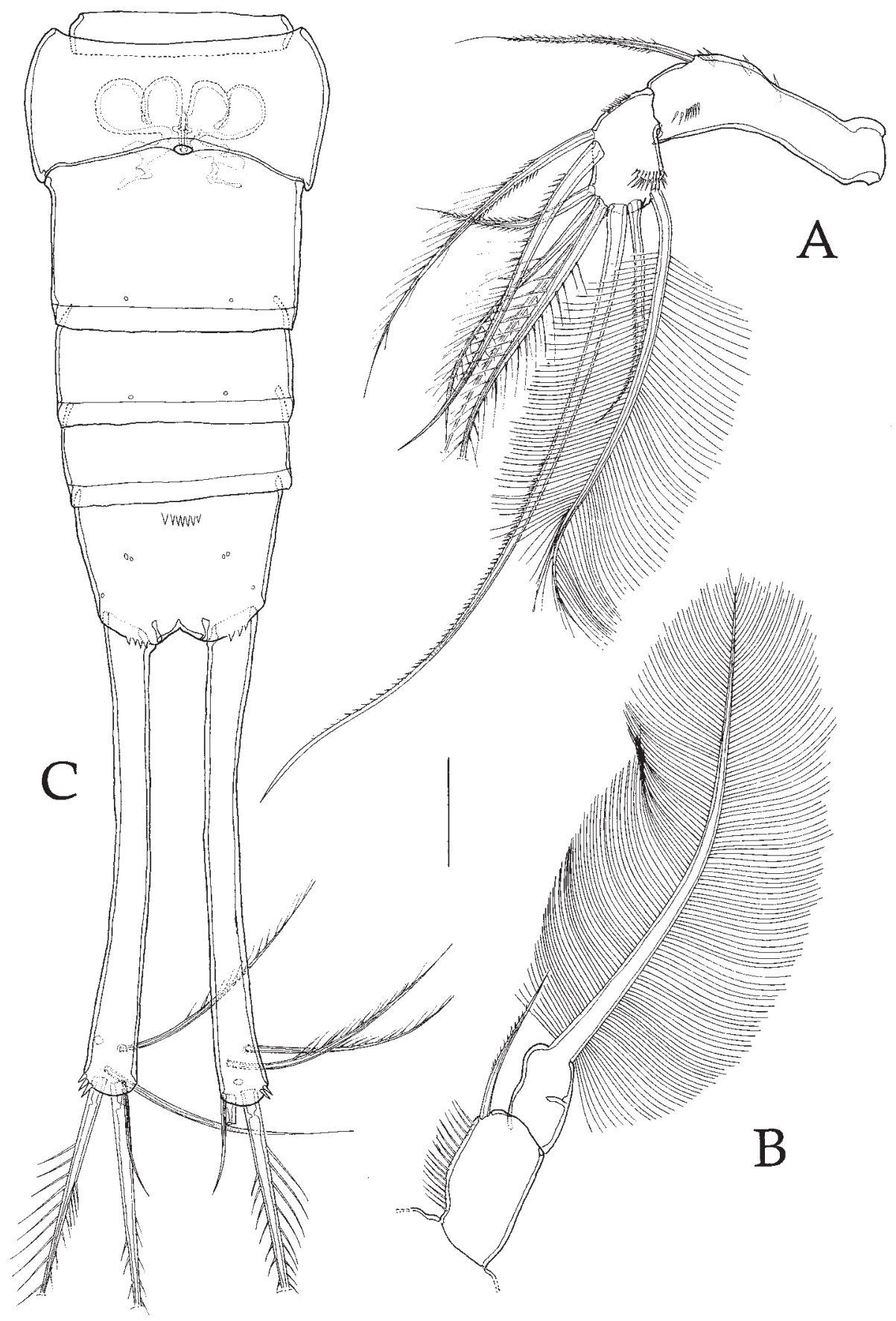

Fig. 2. Schminkepinella plumifera gen.n., sp.n. Female.

A - antenna; B - maxilliped; C - urosome, ventral view. Scale bar $20 \mu \mathrm{m}$.

Рис. 2. Schminkepinella plumifera gen.n., sp.n. Самка.

А — антенна; В - максиллипед; C - уросома, вид с брюшной стороны. Масштаб 20 мкм. 
about 15.5 times as long as wide (Figs 1A-B, 2C), with 6 setae: seta I absent, setae II, III and VII located subterminally on dorsal margin, setae IV, V and VI located terminally.

Antennule 8-segmented (not figured), armature formula beginning with proximal segment: $3+$ aesthetasc, $14+2$ aesthetascs, $2+$ aesthetasc, $3+2$ aesthetascs, 1,2 + aesthetasc, $3+$ aesthetasc, $7+$ aesthetasc.

Antenna (Fig. 2A) 2-segmented; first segment comprising fused asetose coxa, asetose basis and first endopodal segment bearing one inner seta; second segment comprising fused second endopodal segment bearing 2 inner setae, and third endopodal segment bearing 7 setae, outermost ornamented with very long subordinate spinules giving the appearance of a bird's feather.

Mandible (Fig. 3C) with falcate gnathobasis having 2 slender setae on outer margin; palp comprising asetose basis, 1-segmented exopod with 2 setae and 1-segmented endopod with 4 setae.

Maxillule (Fig. 3A) with praecoxal arthrite bearing 5 elements in total; coxa without setae; basis with 3 setae on inner margin; exopod with 4 long bipinnate setae; endopod with 2 outer bipinnate setae and 2 inner naked setae.

Maxilla (Fig. 3D) praecoxa with one endite bearing 3 setae; proximal coxal endite with 2 , distal endite with 3 setae; basal endite with 2 setae; endopod 3-segmented with 2, 2, 2 setae.

Maxilliped (Fig. 2B) 2-segmented; first segment with 1 inner seta; second segment produced into long feather-like seta densely covered with long setules.

Legs 1 to 4 (Figs 4A-B, 5A-C) with 3-segmented rami. Third endopodal segment of legs 1-4 without outer seta. Leg 1 coxa with inner seta; basis without outer seta; third endopodal segment with 4 armature elements in total. Outer basal seta of legs 2 4 reduced in size. Third endopodal segment of leg 3 with 4 armature elements in total. Third endopodal segment of leg 4 with distal inner spine having a broad subordinate spinule proximally; third exopodal segment of this limb with distal outer spine a small and short element. Swimming leg armature formulae:

\begin{tabular}{|c|c|c|c|c|}
\hline & Coxa & Basis & Endopod & Exopod \\
\hline Leg 1 & $0-1$ & $0-\mathrm{I}$ & $\begin{array}{c}0-1 ; 0-1 ; \\
0,2,2\end{array}$ & $\begin{array}{c}\text { I-0; I-1; } \\
\text { III,I,4 }\end{array}$ \\
\hline Leg 2 & $0-1$ & $1-0$ & $\begin{array}{c}0-1 ; 0-2 ; \\
0,2,2\end{array}$ & $\begin{array}{c}\text { I-0; I-1; } \\
\text { III,I,5 }\end{array}$ \\
\hline Leg 3 & $0-1$ & $1-0$ & $\begin{array}{c}0-1 ; 0-2 ; \\
0, I I, 2\end{array}$ & $\begin{array}{c}\text { I-0; I-1; } \\
\text { III,I,5 }\end{array}$ \\
\hline Leg 4 & $0-1$ & $1-0$ & $\begin{array}{c}0-1 ; 0-1 \mathrm{I} ; \\
0, I I, I I\end{array}$ & $\begin{array}{c}\text { I-0; I-1; } \\
\text { II,I,5 }\end{array}$ \\
\hline
\end{tabular}

Leg 5 (Fig. 6B) with well developed intercoxal sclerite, asetose coxa, basis with one outer seta, and 1-segmented exopod bearing one outer spine and one terminal slender bipinnate seta flanked by 2 spines.

Leg 6 located (Fig. 6A) laterally with 1 slender bipinnate seta and 2 short spines, one of them confluent with segment.

Male. Differs from female in following characters:

Body length (measured from frontal rim of cephalosome to caudal margin of telson) $272 \mu \mathrm{m}$.

Antennule short and strait, indistinctly 6-segmented, setation and segmentation as inEinslepinella ulrichi gen.n., sp.n. Furca shorter than in female, 9.2 times as long as wide. Fifth legs single exopodal segment with one additional small and slender seta subterminally on inner margin (Fig. 5E). Leg 6 (Fig. 5D) with 3 armature elements in total. Only one spermatophore present.

Etymology. The specific name refers to the feather-like maxilliped.

Remarks. A second unnamed species of this genus was collected on the 18 August 1993 at a depth of $2995 \mathrm{~m}$ on the lower continental slope of the Barents Sea $\left(82^{\circ} 45.83^{\prime}\right.$ N $40^{\circ} 14.54^{\prime}$ E). One female is mounted on one slide and labelled as Schminkepinella sp. 2 (UNIOL 1998.019/1). This species agrees in almost every feature with $S$. plumifera gen.n., sp.n.with the exception of the following characters: Furca somewhat shorter; third endopodal segment of leg 3 with one additional seta on inner margin (setation formula 3,II,0); third endopodal segment of leg 4 with 2 terminal spines, 1 distal inner spine and 1 long proximal inner seta; third exopodal segment of this limb with distal outer spine of normal shape, i. e. not reduced in size and transformed into a naked seta; leg 5 exopod lacking spine on outer margin, i. e. with 3 armature elements in total, and without spinules along inner margin.

Schminkepinella gen.n. can easily be distinguished from all other cyclopinid genera by the peculiar shape of its maxilliped as it is transformed into a long feather-like structure. Another noteworthy apomorphy of the new genus is the absence of an outer basal seta on the first swimming leg. The absence of an outer element on the distal endopodal segments of legs 1-4 is a unique apomorphy within Schminkepinellidae fam.n., as is the fusion (or lack of separation) of antennary endopodal segments 2 and 3 , and the fusion of the antennary syncoxo-basis with the first endopodal segment. The terminal inner element on the third endopodal segment of leg 3 is a seta in Schminkepinella gen.n., while it is a spine in all other genera of Schminkepinellidae fam.n. The loss of this spinal condition is considered here as a character reversal, this being in my view, the most parsimonious explanation. 


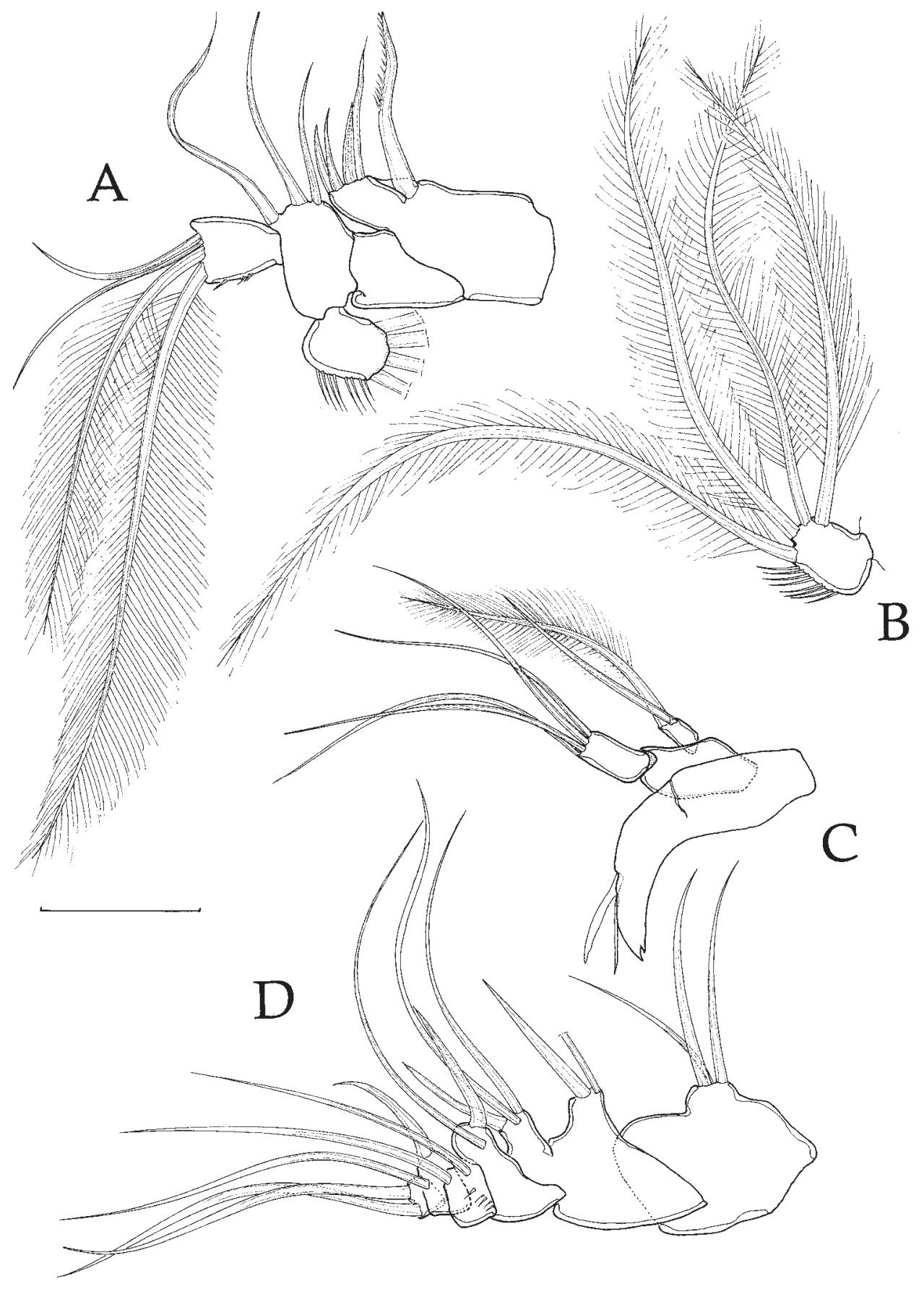

Fig. 3. Schminkepinella plumifera gen.n., sp.n. Female.

A - maxillule; B - maxillulary exopod; C - mandible; D - maxilla. Scale bar $20 \mu \mathrm{m}$.

Рис. 3. Schminkepinella plumifera gen.n., sp.n. Самка.

A - максиллула; В - экзоподит максиллулы; C - мандибула; D - максилла. Масштаб 20 мкм. 


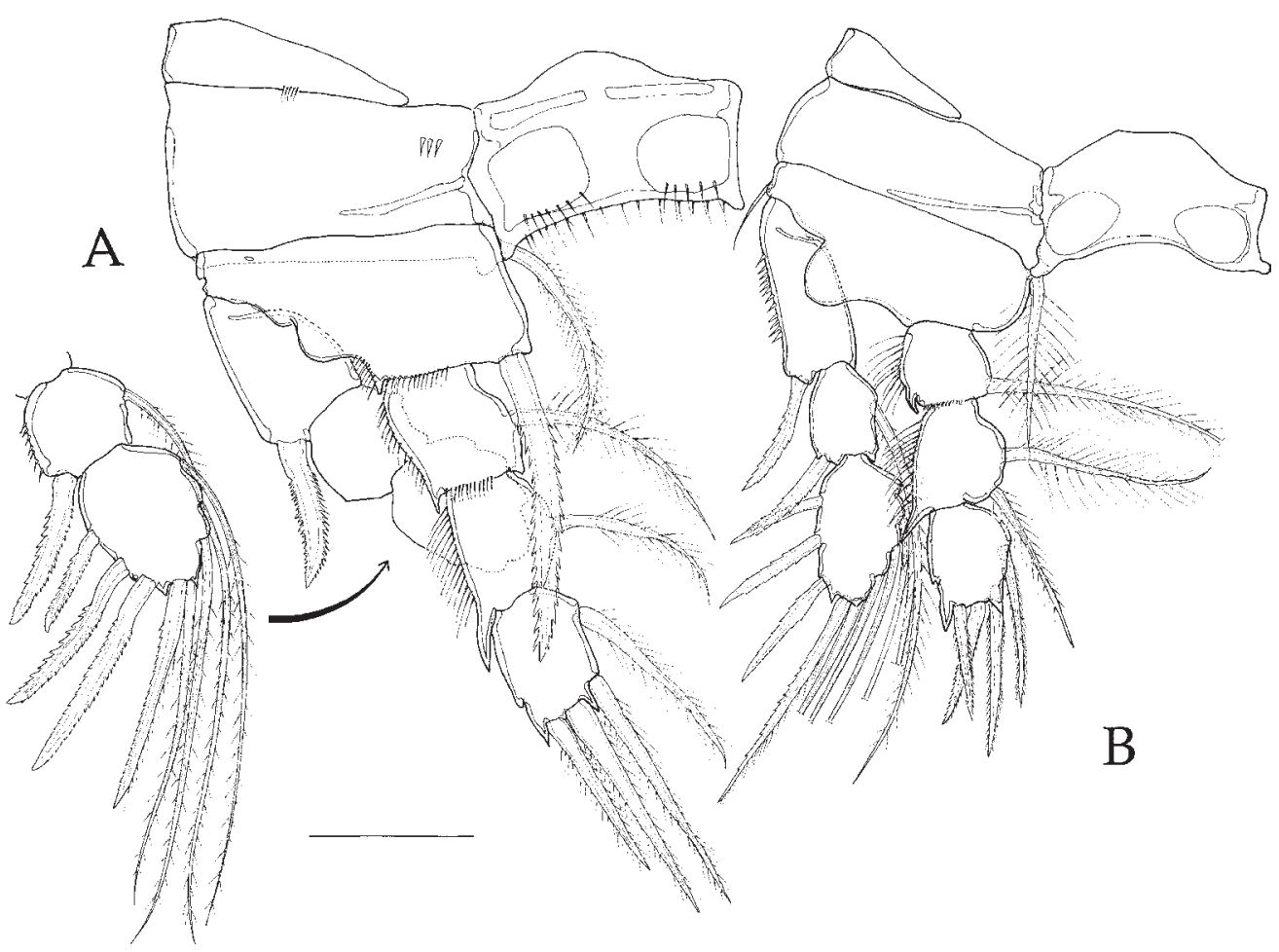

Fig. 4. Schminkepinella plumifera gen.n., sp.n. Female. A - leg 1; B - leg 2. Scale bar $20 \mu \mathrm{m}$.

Рис. 4. Schminkepinella plumifera gen.n., sp.n. Самка.

A - нога 1; В - нога 2. Масштаб 20 мкм.

\section{Einslepinella gen.n.}

Diagnosis (ground pattern). Cyclopoida, Schminkepinellidae. Body cyclopiform. First pedigerous somite free, not covered by a carapace-like extension of the cephalosome. Antennule 8-segmented in female, indistinctly 6-segmented in male. Both sexes with 9 antennulary aesthetascs. Antennulary setae of the rat-tail type (Willen, 1996). Antenna with fused syncoxa and basis, former basis asetose. Mandible with falcate gnathobasis curved inwardly, palp with 1-segmented endopod and 3-segmented exopod, distal endopodal segment confluent with a long and strait spine. Maxillule reduced in size, epipodite asetose. Maxilliped variable shaped at most 5-segmented; first 4 segments asetose, distal segment with 2 setae at most. Swimming legs with 3 segmented rami. First exopodal segment of legs 1-4 without inner seta. First leg without coxal inner seta; basal spine elongate, almost as long as the whole endopod; second endopodal segment with only one inner seta; third endopodal segment with outer seta and outermost terminal elements spine-like; first exopodal segment without spinules along outer margin. Third endopodal segment of leg 2 with both outer and outermost terminal setae as lamellate spines. Third endopodal segment of leg 3 with the outer, the two terminal setae and the distal inner seta transformed into lamellate spines; this segment with sexually dimorphic outer distal corner. Leg 4 with all 5 setae on third endopodal segment and distal inner seta on second endopodal segment as lamellate spines. Leg 5 with well developed intercoxal sclerite, coxa, and basis; endopod 1-segmented with 3 lamellate spines and one seta in female and at most 2-segmented in male, with proximal segment bearing one inner seta and one outer lamellate spine, distal segment with 2 lamellate spines and one seta. Female genital double-somite with arthrodial membrane ventrally, with medially located single copulatory pore; seminal receptacles bilobed; gonopores located laterally, leg 6 with one seta. Male leg 6 with one seta and 2 long spines. Furca elongate, with 6 setae; seta I missing, setae III and VII located on dorsal margin. 


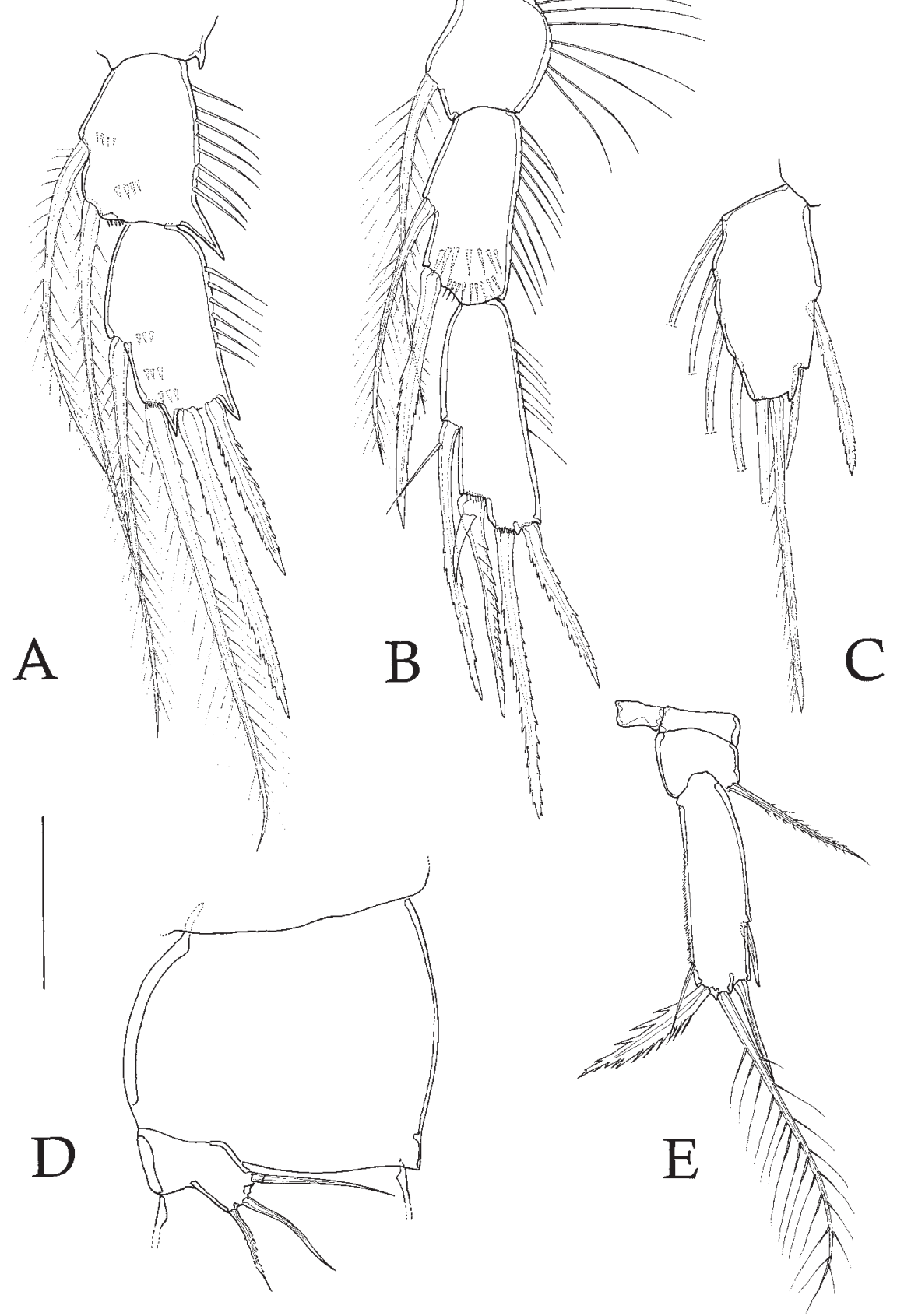

Fig. 5. Schminkepinella plumifera gen.n., sp.n. A-C - female, D-E - male. A - leg 3 middle and distal endopodal segments; B - leg 4 endopod; C - leg 4 third exopodal segment; D - leg 6, lateral view; E - leg 5. Scale bar $20 \mu \mathrm{m}$.

Рис. 5. Schminkepinella plumifera gen.n., sp.n. А-C - самка, D-E - самец.

$\mathrm{A}-$ средний и дистальный членики эндоподита 3-й ноги; В - эндоподит 4-й ноги; C - 3-й членик экзоподита 4-й ноги; D - нога 6, вид сбоку; Е - нога 5. Масштаб 20 мкм. 


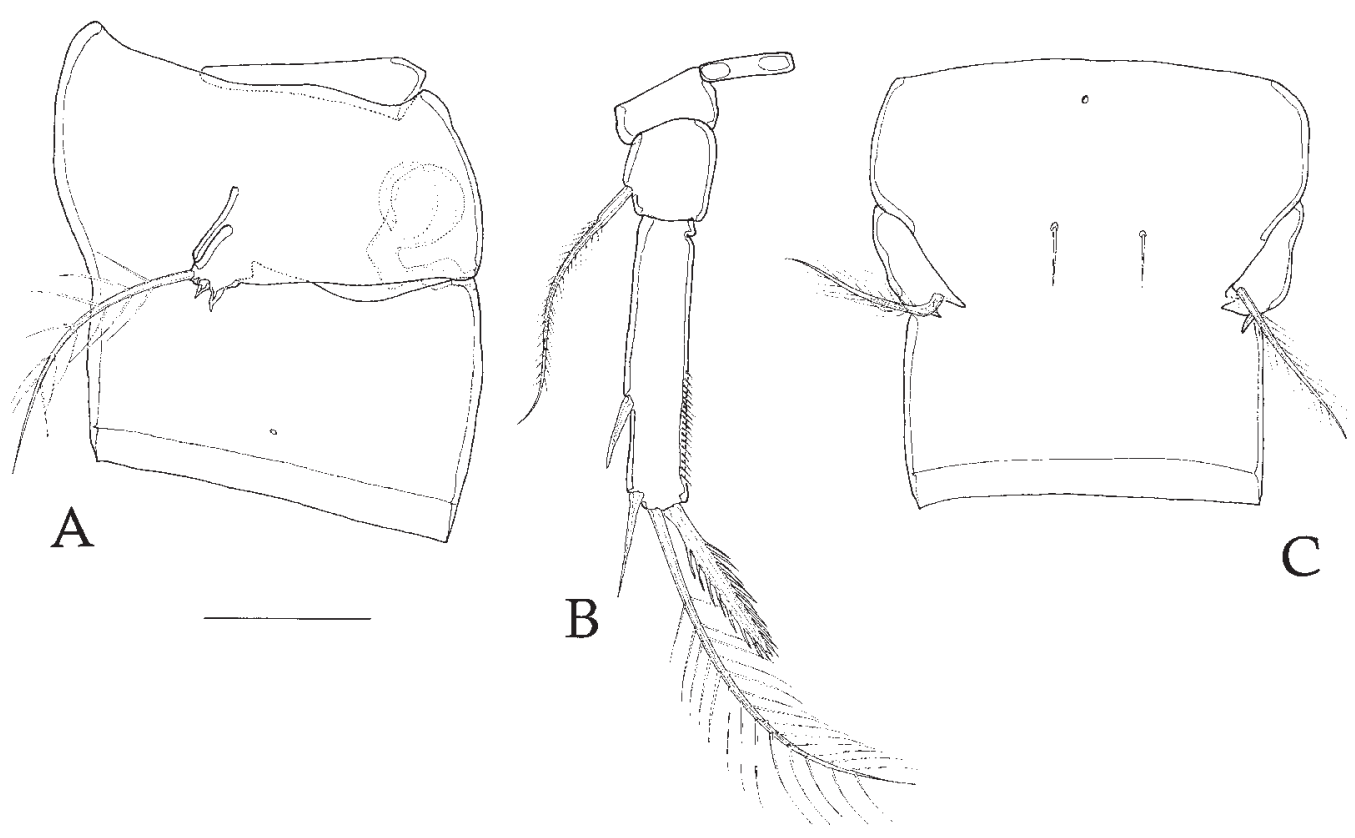

Fig. 6. Schminkepinella plumifera gen.n., sp.n. Female.

A — genital double-somite, lateral view; B - leg 5; C - genital double-somite, dorsal view. Scale bar $20 \mu \mathrm{m}$. Рис. 6. Schminkepinella plumifera gen.n., sp.n. Самка.

$\mathrm{A}$ - генитальный двойной сегмент, вид сбоку В - 5-я нога; С — генитальный двойной сегмент, вид со спинной стороны. Масштаб 20 мкм.

Type species: Einslepinella ulrichi gen.n., sp.n. Other species: E. mediana sp.n., E. alignatha sp.n.

Etymology. This genus is dedicated to the memory of late Dr. Ulrich Einsle, who devoted his life to the study of cyclopoid copepods. Dr. Einsle encouraged me to study the insufficiently known cyclopoid family Cyclopinidae. The type species of this genus is also named after him. The generic name is formed by combination of the name 'Einsle' with 'pinella' which is part of the name of the related genus Cyclopinella Sars, 1913.

\section{Einslepinella ulrichi sp.n.}

Material. Holotype female dissected and mounted on 11 slides (UNIOL 1998.011/1-1998.011/11); allotype male dissected and mounted on 10 slides (UNIOL 1998.012/1-1998.012/10); paratype: female (UNIOL 1998.13/1) mounted on one slide.

Locus typicus. Holotype and allotype collected at a depth of $529 \mathrm{~m}$ on the continental slope north-western off Franz-Joseph-Land ( $\left.82^{\circ} 07.37^{\prime} \mathrm{N} 42^{\circ} 32.79^{\prime} \mathrm{E}\right)$ on the 21 August 1993. Paratype collected in the harbour of $\mathrm{Ny}$ Elesund (Spitzbergen) at $8 \mathrm{~m}$ depth in June 1997 (leg. J. Dürbaum).
Female. Body cyclopiform. Body length (measured from frontal rim of cephalosome to caudal margin of telson) $550 \mu \mathrm{m}$. First pedigerous somite free, covered neither laterally nor dorsally by a caudally extending carapace-like extension of cephalosome (Fig. 7A-B). Urosome comprising fifth pedigerous somite, genital double-somite, 2 free abdominal somites and telson. Well developed pseudosomite present ventrally between genital double-somite and fifth pedigerous somite. Pseudosomite ornamented medially with minute spinules (Fig. 12A). Arthrodial membrane separating posterior thoracic and anterior abdominal somites present ventrally absent dorsally, with a medially interrupted row of spinules ventrally and serrate skirt posteriorly. Serrate skirt also on the 2 free abdominal somites and on the telson only ventrally. Telson with a symmetrical pattern of larger and smaller pores on ventral surface. Furca elongate, about 8 times as long as wide, with 6 setae: seta I absent, seta II located at one half of the length of the furca on outer margin, seta III located subterminally on dorsal margin, setae IV-VI terminally, seta VII located on dorsal face. 


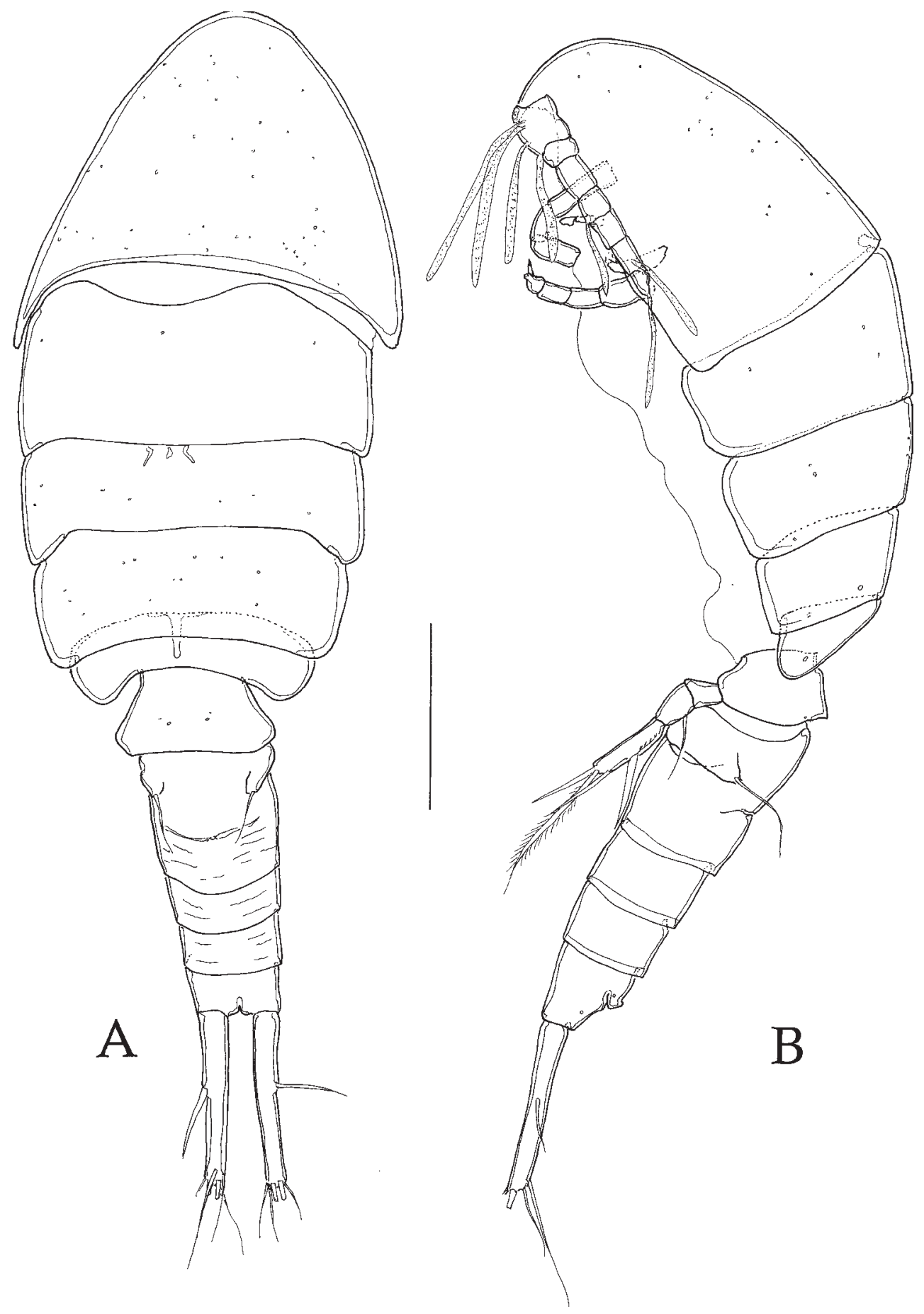

Fig. 7. Einslepinella ulrichi gen.n., sp.n. Habitus of female. A - dorsal view; B - lateral view. Scale bar $100 \mu \mathrm{m}$.

Рис. 7. Einslepinella ulrichi gen.n., sp.n. Общий вид самки. А - вид со спинной стороны; В - вид сбоку. Масштаб 100 мкм. 


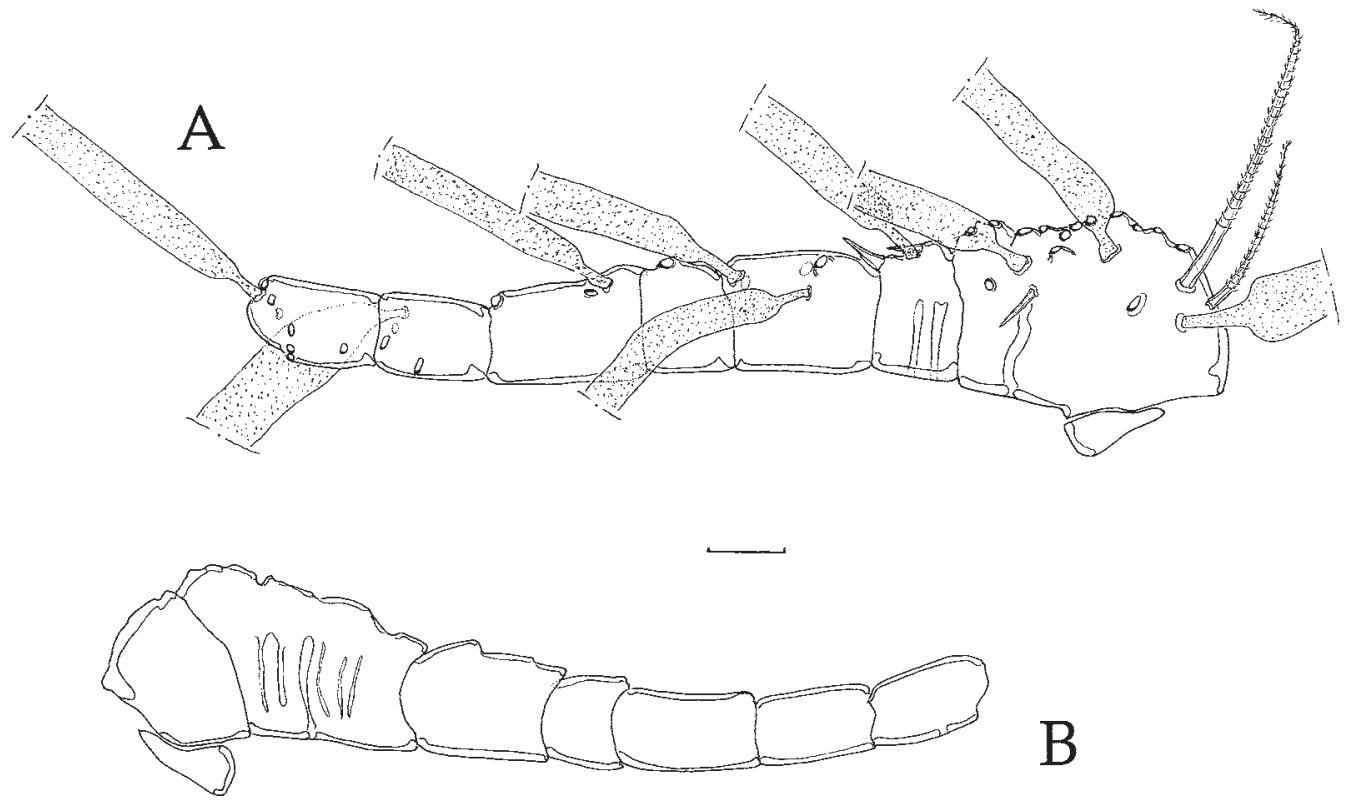

Fig. 8. A: Einslepinella ulrichi gen.n., sp.n. Female, antennule, two rat-tail setae drawn on proximal segment, all others represented by their insertion point. B: E. mediana sp.n. Female, antennule, armature elements omitted.

Scale bar $20 \mu \mathrm{m}$.

Рис. 8. A: Einslepinella ulrichi gen.n., sp.n. Самка, антеннула, две хвостовидные щетинки зарисованы на проксимальном членике, все другие щетинки обозначены в точках их крепления. В: E. mediana sp.n. Самка, антеннула, вооружение не показано. Масштаб 20 мкм.

Antennule short, indistinctly 7-segmented (Fig. 8A). Proximal segments with traces of subdivisions. Antennulary setae of the 'rat-tail' type (Willen, 1996). Armature beginning with proximal segment: $17+3$ aesthetascs, $2+$ aesthetasc, $3+2$ aesthetascs, 1, $2+$ aesthetasc, $3+$ aesthetasc, $7+$ aesthetasc.

Antenna (Fig. 9A) with fused syncoxa and basis, with rows of spinules on anterior and posterior margins. Former basis asetose. First endopodal segment with large inner seta and rows of long spinules on anterior and posterior margins; second endopodal segment with one inner seta, third segment with 5 setae in total.

Mandible, maxillule and maxilla very reduced in size. Mandible (Fig. 9B) with falcate inwardly curved gnathobasis bearing one long seta on outer margin; palp comprising asetose basis; 1-segmented endopod with 5 setae; and 3-segmented exopod with setal formula 1, 1, 1. Distal segment confluent with a strait and very long seta.
Maxillule (Fig. 9D) with indistinct segmentation, on inner margin with a proximal praecoxal lobe bearing 4 setae, and a distal baseoendopodal lobe bearing 4 setae in total; distally with 1 -segmented exopod bearing 4 setae.

Maxilla 4-segmented (Fig. 9C), proximal praecoxal lobe with 3 setae, distal lobe with 1 seta; coxa with 2 endites bearing 2 setae each; basis with 2 setae on inner margin, endopod 1-segmented with 6 setae in total.

Maxilliped 5-segmented (Fig. 9E); syncoxa asetose, with row of spinules on anterior margin; basis asetose, with rows of long spinules along inner margin; first endopodal segment asetose, with small protuberance on inner margin covered by small spinules; second segment almost at right angles to first one, asetose, with 2 hook-like teeth on inner margin; third segment small, confluent terminally with a long and strait spine, and with a slender seta on outer margin.

Leg 1-4 with 3 segmented rami (Figs 10A-C, 11A). Swimming leg armature formulae: 


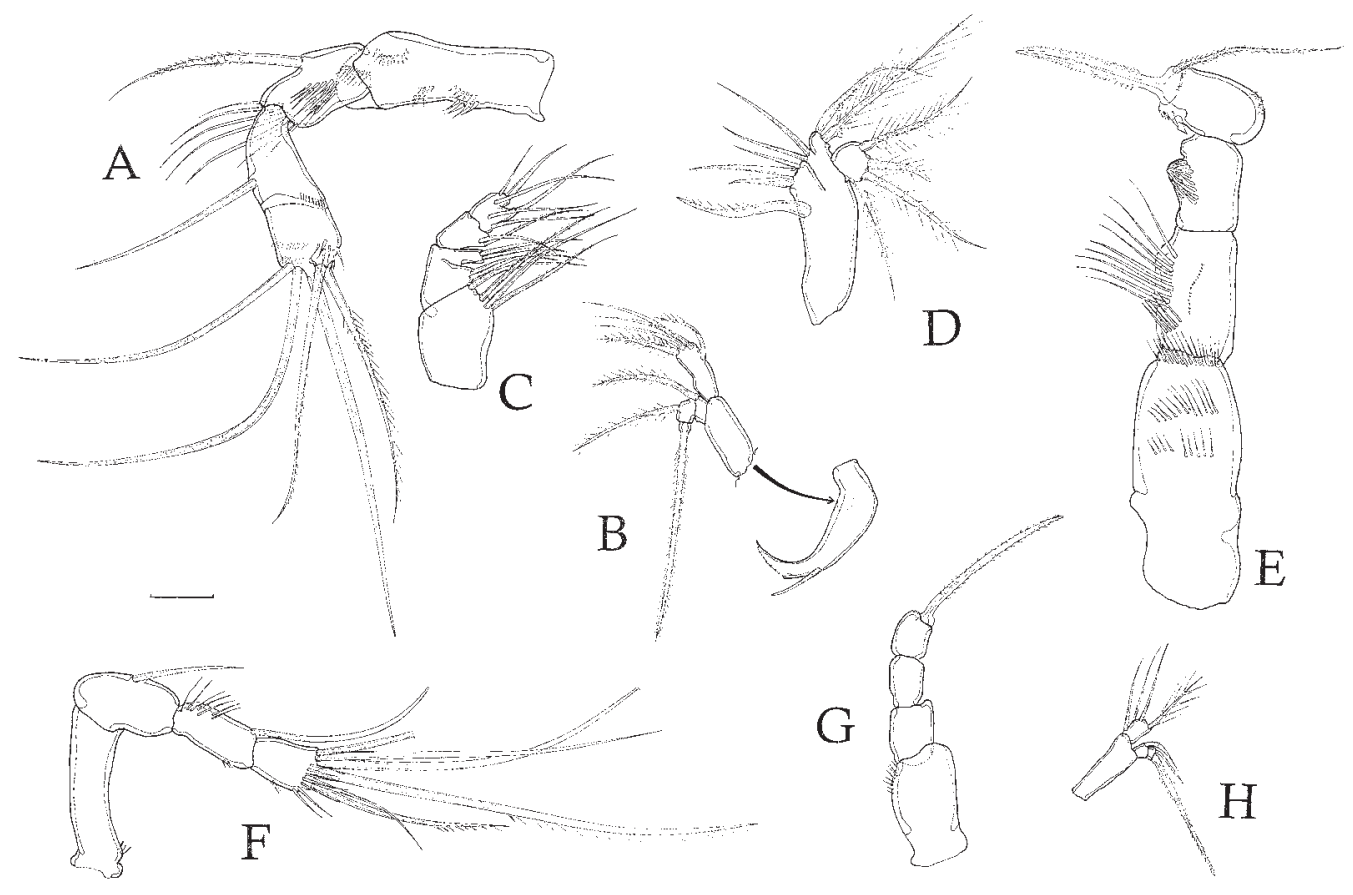

Fig. 9. A-E: Einslepinella ulrichi gen.n., sp.n. Female. F-H: E. mediana sp.n.

A - antenna; B - mandible; C - maxilla; D - maxillule; E - maxilliped; F — antenna; G - maxilliped; H mandibular palp. Scale bar $20 \mu \mathrm{m}$.

Рис. 9. А-E: Einslepinella ulrichi gen.n., sp.n. Самка. F-H: E. mediana sp.n.

А — антенна; В — мандибулла; C — максилла; D — максиллула; Е — максиллипед; F — антенна; G максиллипед; Н - пальпа мандибул. Масштаб 20 мкм.

\begin{tabular}{|c|c|c|c|c|}
\hline & Coxa & Basis & Endopod & Exopod \\
\hline Leg 1 & $0-0$ & $1-\mathrm{I}$ & $\begin{array}{c}0-1 ; 0-1 ; \\
\text { I,I1,2 }\end{array}$ & $\begin{array}{c}\text { I-0; I-1; } \\
\text { III,I,4 }\end{array}$ \\
\hline Leg 2 & $0-1$ & $1-0$ & $\begin{array}{c}0-1 ; 0-2 ; \\
\text { I,I1,3 }\end{array}$ & $\begin{array}{c}\text { I-0; I-1; } \\
\text { III,I,5 }\end{array}$ \\
\hline Leg 3 & $0-1$ & $1-0$ & $\begin{array}{c}0-1 ; 0-2 ; \\
\text { I,II,I2 }\end{array}$ & $\begin{array}{c}\text { I-0; I-1; } \\
\text { III,I,5 }\end{array}$ \\
\hline Leg 4 & $0-1$ & $1-0$ & $\begin{array}{c}0-1 ; 0-1 I ; \\
\text { I,II,II }\end{array}$ & $\begin{array}{c}\text { I-0; I-1; } \\
\text { II,I,5 }\end{array}$ \\
\hline
\end{tabular}

Leg 1 (Fig. 10A), intercoxal sclerite ornamented on both sides with a cluster of long spinules; coxa without inner seta; basis with long outer seta and long inner spine reaching to the middle of the distal endopodal segment. First and second endopodal segments with one inner seta each; third segment with 2 inner setae, 1 terminal inner seta, 1 terminal outer spine, and 1 outer spine. First exopodal segment without inner seta and without spinules along outer margin. Leg 2 distal endopodal segment with outer and outermost terminal setae as a spine (Fig. 10C). Leg 3 with outer, two terminal and distal inner setae transformed into spines (Fig. 10B). Leg 4 with all 5 setae on third endopodal segment and distal inner seta on second endopodal segment as a spine (Fig. 11A).

Leg 5 (Fig. 11B) with well developed intercoxal sclerite, coxa asetose, with row of 4 long spinules on anterior margin; basis with one outer seta, and a small serrate apron on anterior margin; 1-segmented exopod with a row of long spinules along outer margin, with 1 outer lamellate spine and 1 terminal slender long seta flanked by 2 lamellate spines.

Leg 6 (Fig. 13C) located laterally, with 1 long and slender seta and two spines fused to segment.

Single copulatory pore located medially on genital double-somite extending into a short copulatory tube leading to a pair of bilobed cavities, presumably the seminal receptacles. 


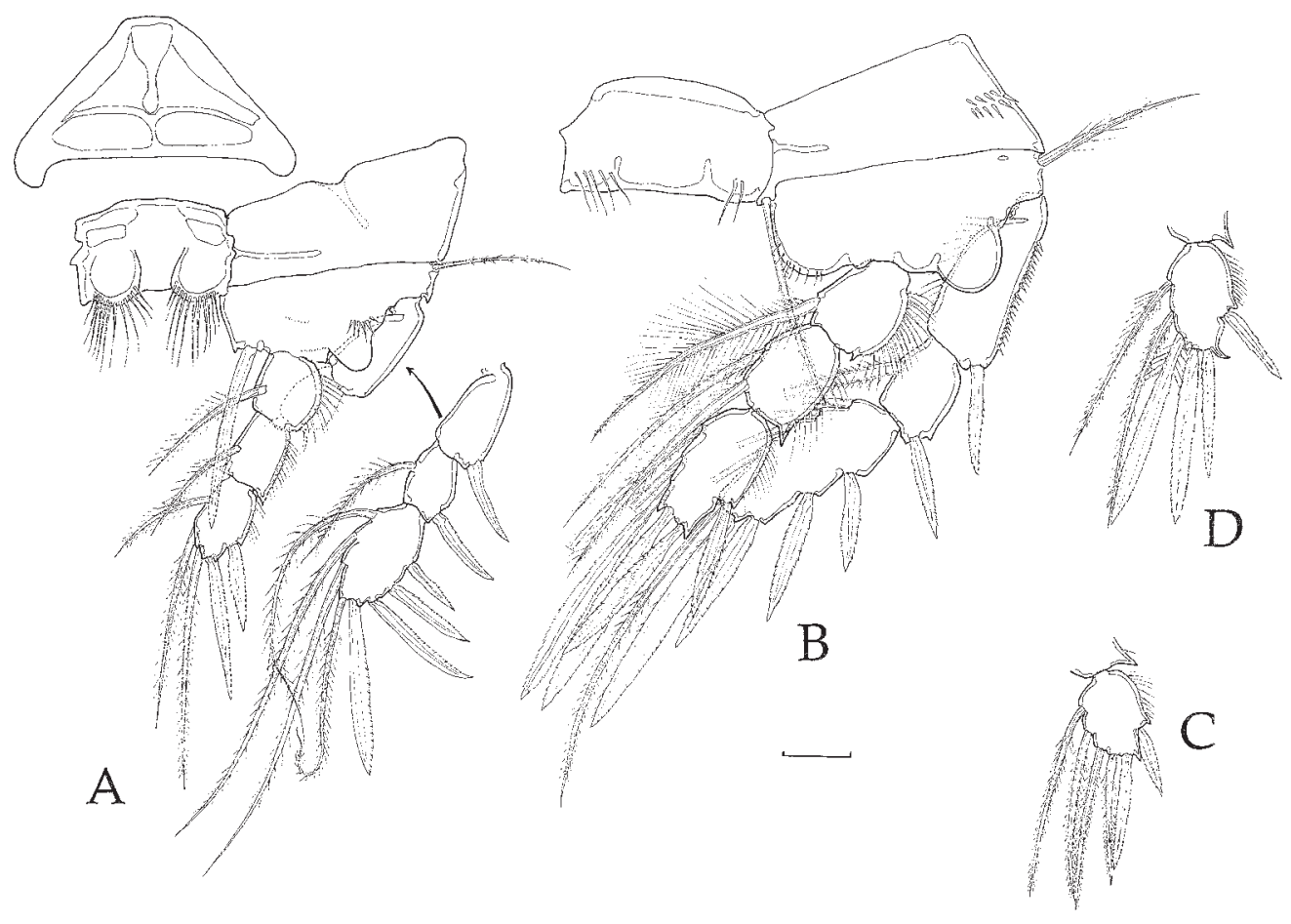

Fig. 10. Einslepinella ulrichi gen.n., sp.n.

A - leg 1, female; B - leg 3, female; C - leg 2, female; D - third endopodal segment of leg 3, male. Scale bar 20 $\mu \mathrm{m}$.

Рис. 10. Einslepinella ulrichi gen.n., sp.n.

A - нога 1, самка; В - нога 3, самка; C - нога 2, самка; D - третий членик эндоподита 3-й ноги, самец. Масштаб 20 мкм.

Male. Differs from female in following characters: Body length (measured from frontal rim of cephalosome to caudal margin of telson) $484 \mu \mathrm{m}$.

Antennule short and strait, indistinctly 6-segmented, showing different fusion patterns in dorsal and ventral sides (Fig. 11D-E). Neocopepodan geniculation less pronounced, present between segments 4 and 5 . Armature formula beginning with proximal segment: $17+3$ aesthetascs, $5+$ aesthetasc, $3+2$ aesthetascs, $1,4+$ aesthetasc, $9+2$ aesthetascs.

Third endopodal segment of leg 3 with outer distal corner produced into a curved hook (Fig. 10D).

Leg 5 (Fig. 11C) with 2-segmented exopod; first segment with long spinules along outer margin and armed with one outer lamellate spine as well as one slender inner seta; second segment with one terminal long and slender seta flanked by 2 lamellate spines.
Leg 6 a big ventro-laterally located plate (Fig. $13 \mathrm{~A}-\mathrm{B}$ ) covering gonopore and armed with 2 spines and one outer slender seta.

Number of spermatophores unknown.

\section{Einslepinella mediana sp.n.}

Material. Holotype: female dissected and mounted on 9 slides (UNIOL 1998.014/1-1998.014/9); paratype: female mounted on 1 slide (UNIOL 1998.015/1).

Locus typicus. Holotype collected on the 9. August 1993 at $449 \mathrm{~m}$ depth in the Bear Island Trough, Barents Sea ( $73^{\circ} 38,8^{\prime}$ N 22 $\left.55,2^{\prime} \mathrm{E}\right)$; paratype collected on the 26 August 1993 at $156 \mathrm{~m}$ depth in the Vilkitzky Strait (78 $\left.01,9^{\prime} \mathrm{N} 102^{\circ} 17,5^{\prime} \mathrm{E}\right)$.

This species differs from E. ulrichi gen.n., sp.n. in the following characters:

Female. Body length (measured from frontal rim of cephalosome to caudal margin of telson) $381 \mu \mathrm{m}$. 


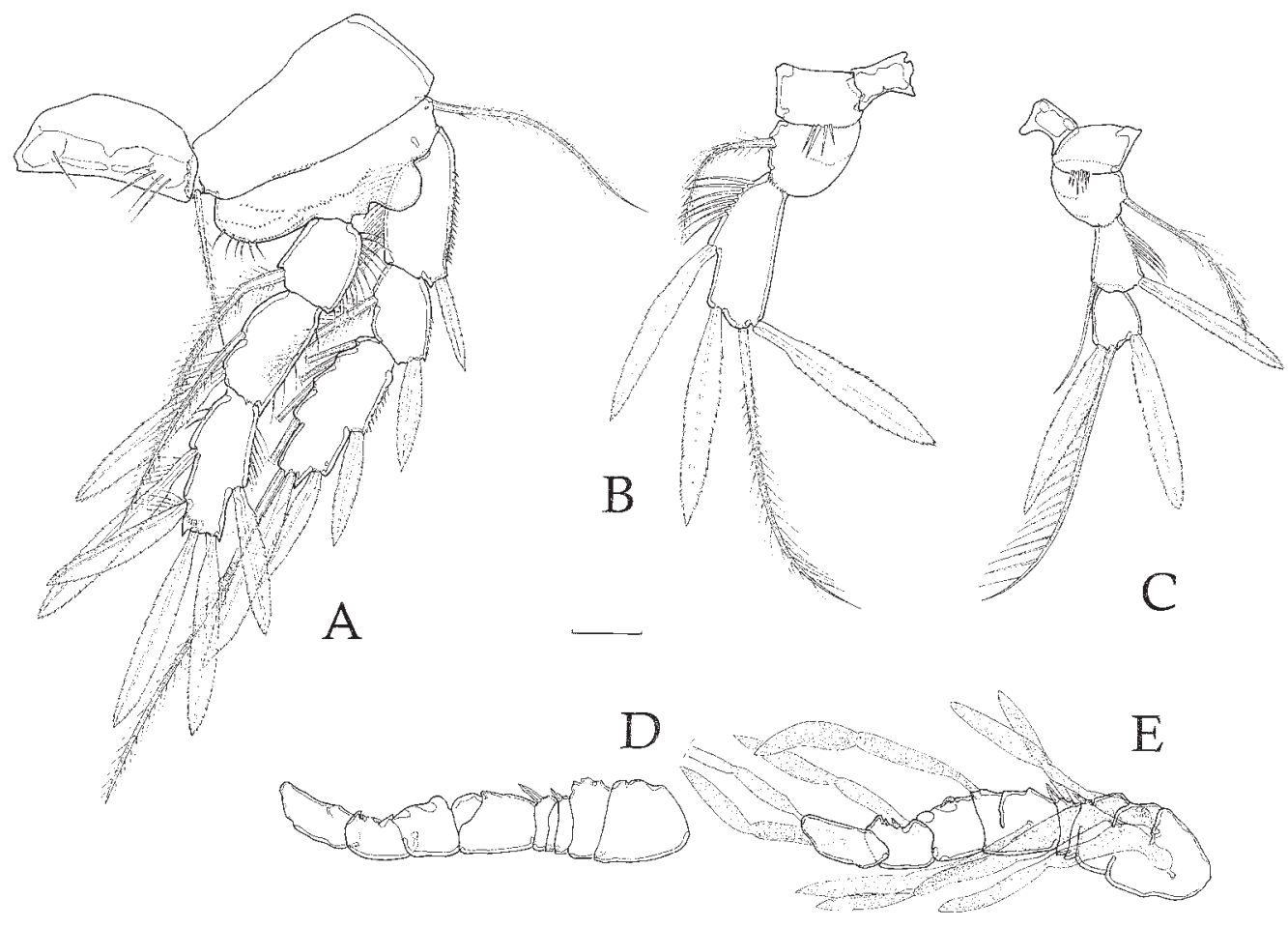

Fig. 11. Einslepinella ulrichi gen.n., sp.n.

A - leg 4, female; B - leg 5, female; C - leg 5, male; D — antennule, male, dorsally, setae and aesthetascs omitted; $\mathrm{E}$ - antennule, male, ventrally, setae and aesthetascs omitted. Scale bar $20 \mu \mathrm{m}$.

Рис. 11. Einslepinella ulrichi gen.n., sp.n.

A - нога 4, самка; В - нога 5, самка; C - нога 5, самец; D - антеннула, самка, вид со спинной стороны, щетинки и эстетаски не показаны; Е - антеннула, самец, вид с брюшной стороны, щетинки и эстетаски не показаны. Масштаб 20 мкм.

Antennule 8-segmented due to a proximal subdivision of first segment (Fig. 8 B). Armature formula beginning with proximal segment: $3+$ aesthetasc, 14 +2 aesthetascs, $2+$ aesthetasc, $3+2$ aesthetascs, 1 , $2+$ aesthetasc, $3+$ aesthetasc, $7+$ aesthetasc.

Antenna (Fig. 9F) much more slender than in preceding species, without ornamentation of long spinules on first and second segments, distal segment with 6 setae.

All mouthparts much more reduced in size than those of the type species of the genus. Mandibular endopod (Fig.9H) with 4 setae only.

Maxilliped small (Fig. 9G), lacking ornamentation of long spinules; third segment produced into a slightly curved spine.

Leg 1, third endopodal segment with one additional inner seta, i. e. with 6 armature elements in total.
Swimming leg armature formulae:

\begin{tabular}{|c|c|c|c|c|}
\hline & Coxa & Basis & Endopod & Exopod \\
\hline Leg 1 & $0-0$ & $1-\mathrm{I}$ & $\begin{array}{c}0-1 ; 0-1 \\
\text { I,I1,3 }\end{array}$ & $\begin{array}{c}\text { I-0; I-1; } \\
\text { III,I,4 }\end{array}$ \\
\hline Leg 2 & $0-1$ & $1-0$ & $\begin{array}{c}0-1 ; 0-2 ; \\
\mathrm{I}, \mathrm{I} 1,3\end{array}$ & $\begin{array}{c}\text { I-0; I-1; } \\
\text { III,I,5 }\end{array}$ \\
\hline Leg 3 & $0-1$ & $1-0$ & $\begin{array}{c}0-1 ; 0-2 ; \\
\text { I,II,I2 }\end{array}$ & $\begin{array}{c}\text { I-0; I-1; } \\
\text { III,I,5 }\end{array}$ \\
\hline Leg 4 & $0-1$ & $1-0$ & $\begin{array}{c}0-1 ; 0-1 \mathrm{I} ; \\
\text { I,II,II }\end{array}$ & $\begin{array}{c}\text { I-0; I-1; } \\
\text { II,I,5 }\end{array}$ \\
\hline
\end{tabular}

Leg 5 (Fig. 15E) without row of long spinules on anterior surface of coxa; exopod with long spinules on outer margin, and with 3 small spinules along 


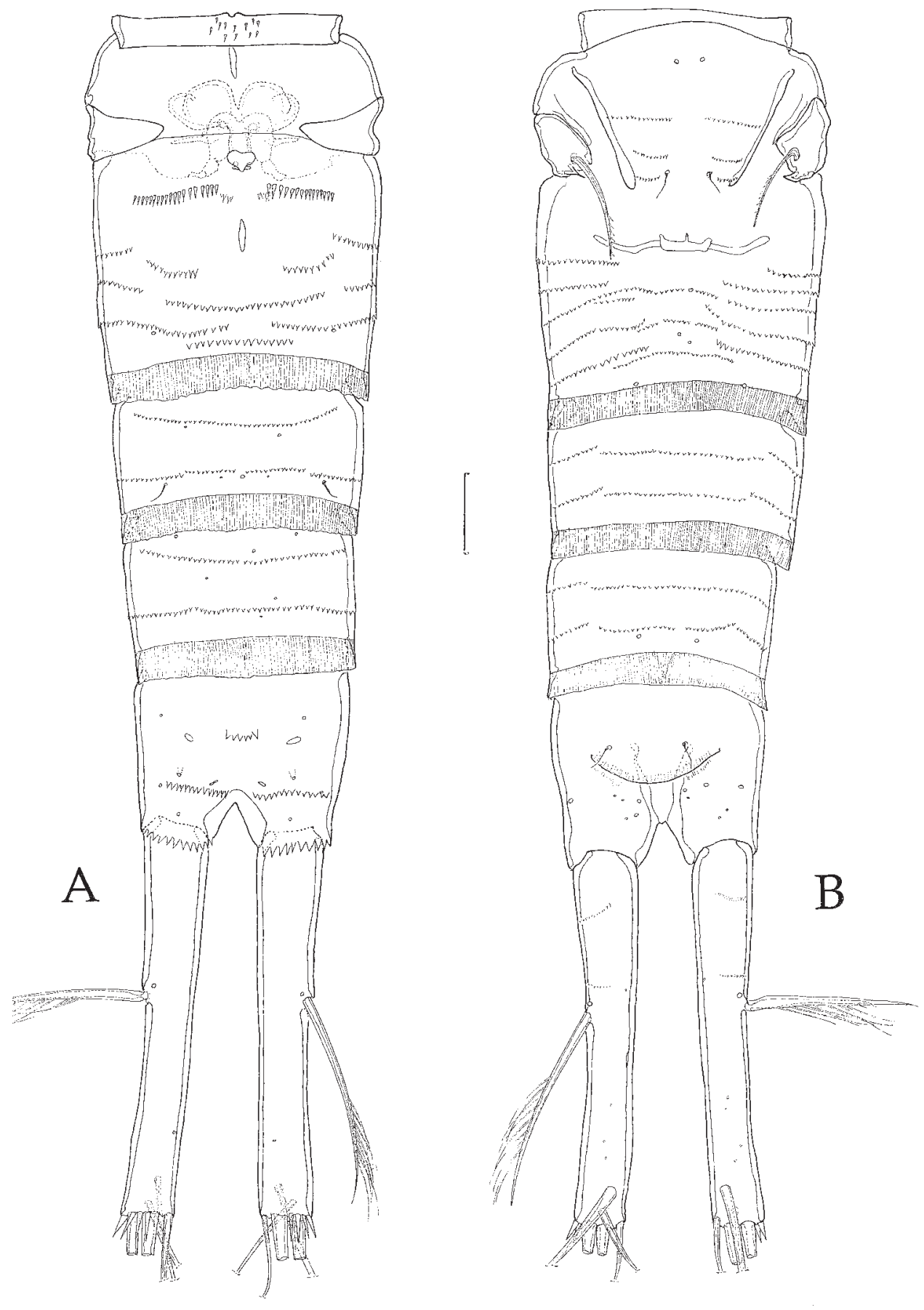

Fig. 12. Einslepinella ulrichi gen.n., sp.n. Female urosome.

A - ventral view; B - dorsal view. Scale bar $20 \mu \mathrm{m}$.

Рис. 12. Einslepinella ulrichi gen.n., sp.n. Уросома самки.

А - вид с брюшной стороны; В - вид со спинной стороны. Масштаб 20 мкм. 

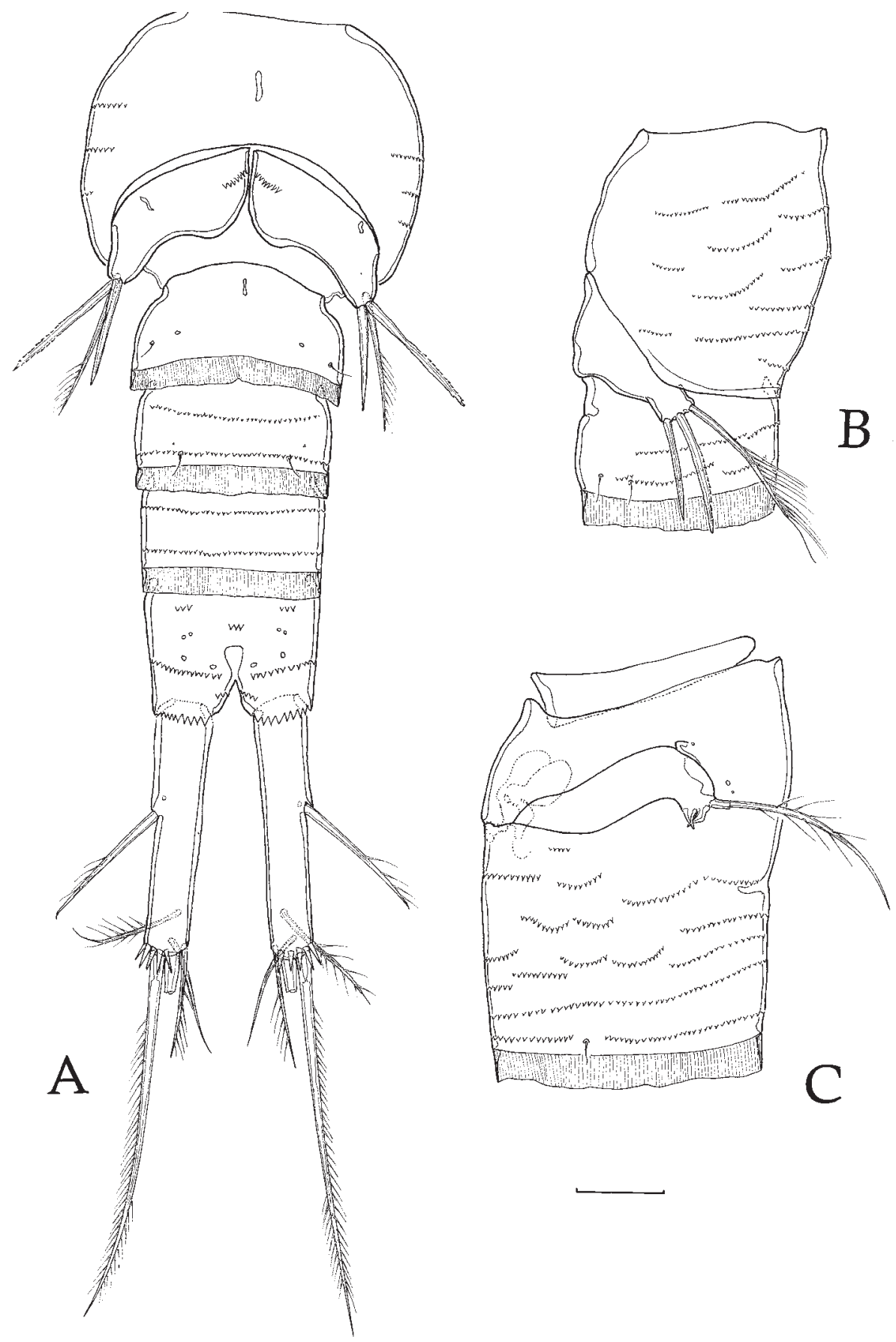

Fig. 13. Einslepinella ulrichi gen.n., sp.n.

A - urosome, male, ventral view; B - leg 6, male, lateral view; C - genital double-somite, female, lateral view. Scale bar $20 \mu \mathrm{m}$.

Рис. 13. Einslepinella ulrichi gen.n., sp.n.

A - уросома, самец, вид с брюшной стороны; В - нога 6, самец, вид сбоку; С - генитальный двойной сегмент, самка, вид сбоку. Масштаб 20 мкм. 

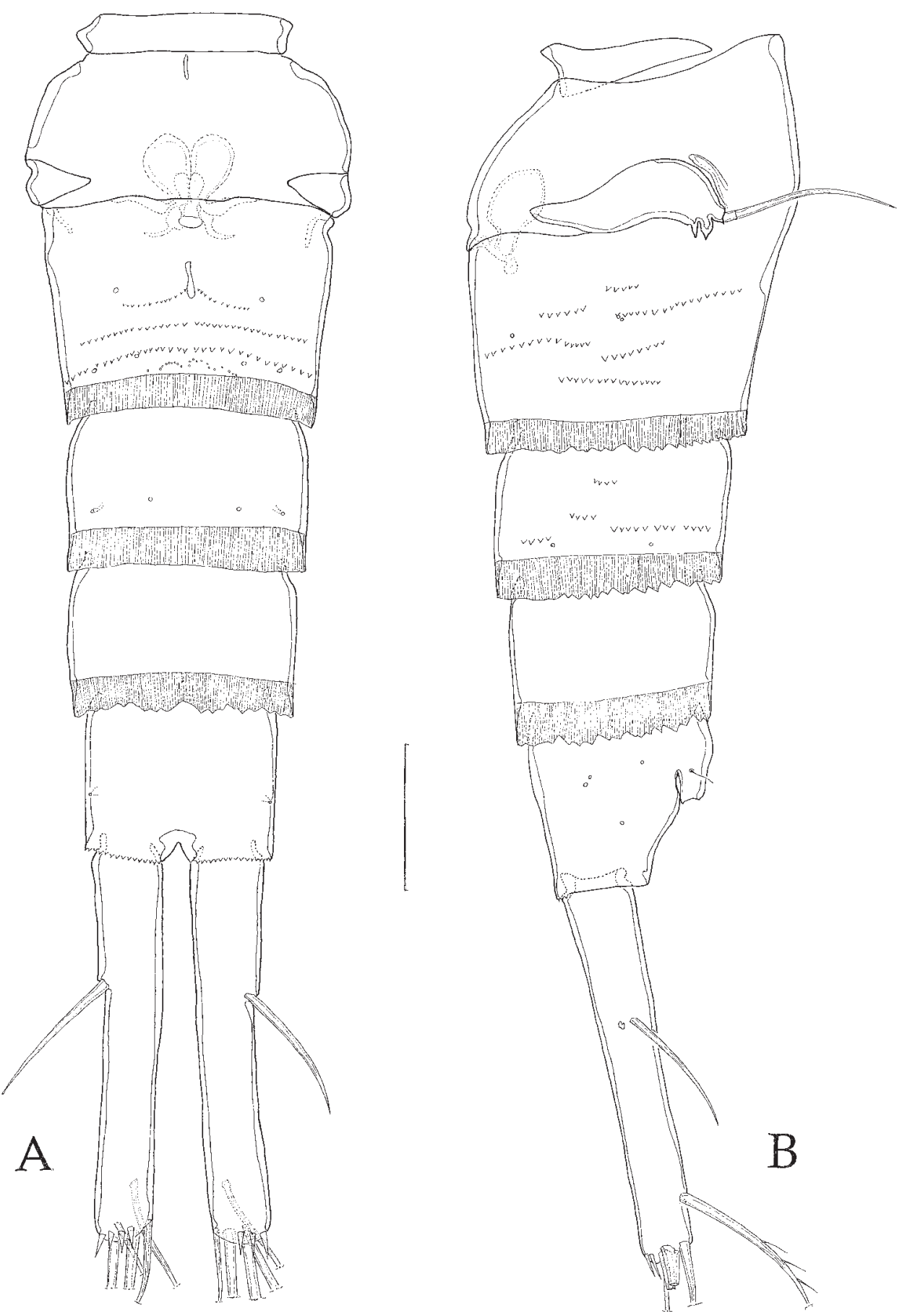

Fig. 14. Einslepinella mediana sp.n. Female urosome. A - ventral view; B - lateral view. Scale bar $20 \mu \mathrm{m}$. Рис. 14. Einslepinella mediana sp.n. Уросома самки. А - вид с брюшной стороны; В - вид сбоку. Масштаб 20 мкм. 


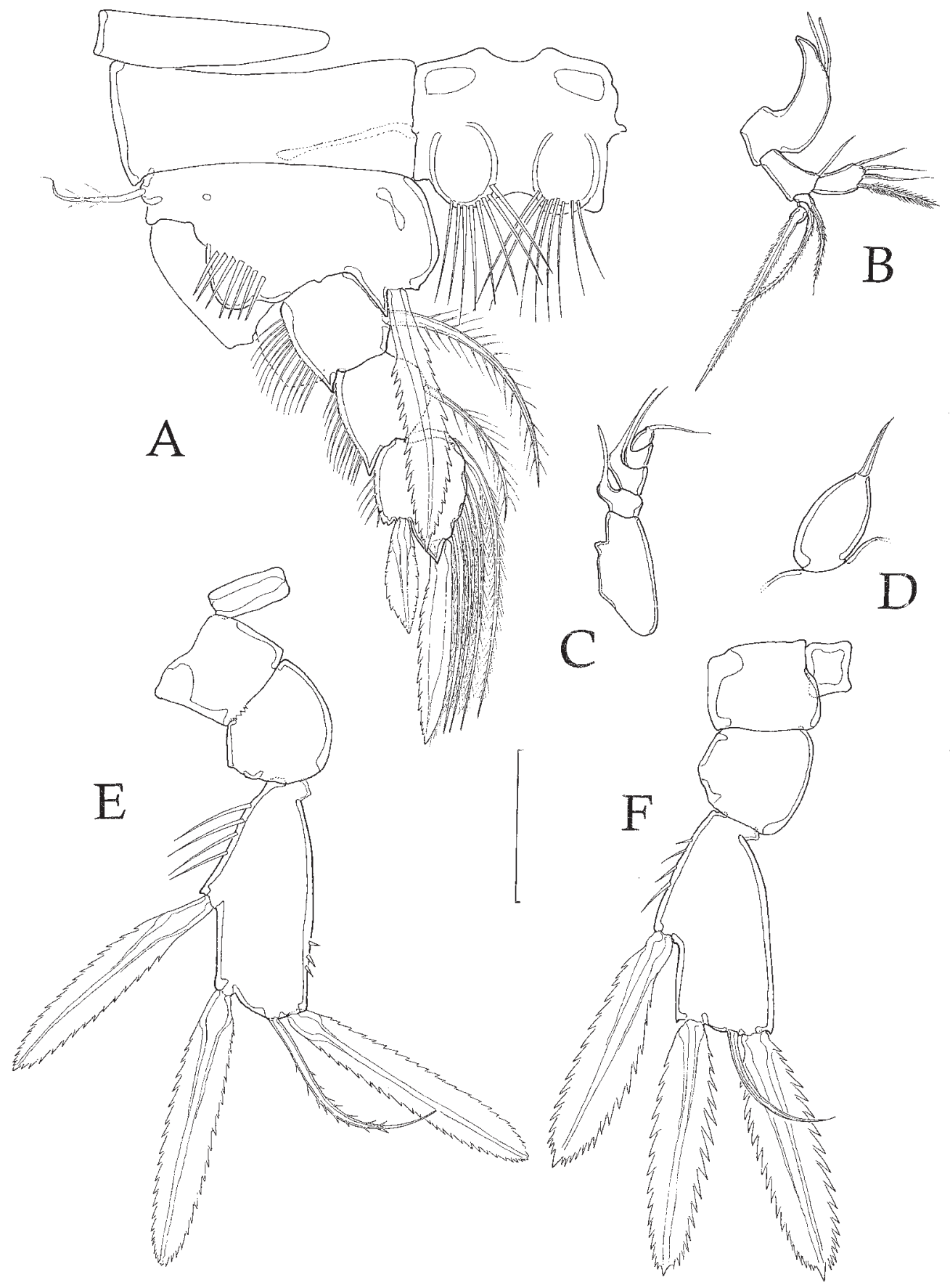

Fig. 15. A-D, F: Einslepinella alignatha sp.n., female. E - Einslepinella mediana sp.n., leg 5, female. A - leg 1 (exopod omitted); B - mandible; C — maxilla; D - maxilliped; F — leg 5; Scale bar $20 \mu \mathrm{m}$. Рис. 15. A-D, F: Einslepinella alignatha sp.n., самка. E: Einslepinella mediana sp.n. нога 5, самка. A — нога 1 (экзоподит не показан); В — мандибула; C - максилла; D — максиллипед; F — нога 5. Масштаб 20 мкм. 
inner margin; terminal seta not reaching the end of inner spine.

Urosome (Fig. 14 A-B) with fewer rows of serrated frills which are mainly restricted to the genital double-somite and first free abdominal somite. Second free abdominal somite and telson without ornamentation.

Male. Unknown.

Etymology. The specific name "mediana" refers to the intermediate size of this species in comparison with the other species of the genus.

\section{Einslepinella alignatha sp.n.}

Material. Holotype: female, dissected and mounted on 4 slides (UNIOL 1998.020/1-1998.020/4); paratype: female dissected and mounted on 9 slides (UNIOL 1998.021/1-1998.021/9).

Locus typicus. Holotype and paratype collected on the 6 September 1993 at a depth of $256 \mathrm{~m}$ in the Laptev Sea, Arctic Ocean $\left(78^{\circ} 04,5^{\prime}\right.$ N $133^{\circ} 36,47^{\prime}$ E).

This species is similar to E. mediana sp.n. but is smaller. Body length (measured from frontal rim of cephalosome to caudal margin of telson) $308 \mu \mathrm{m}$. Antennule and antenna as E. mediana sp.n. in segmentation and setation. Mouth parts even more reduced than in E. mediana sp.n. Mandible very small (Fig. 15B), endopod with 4 apical setae and an additional one at its very base on inner margin. I was unable to discern clearly if this seta actually belongs to the basis or to the endopod.

Maxilla rudimentary, 5-segmented (Fig. 15C), praecoxa asetose, coxa, basis, and 2 endopodal segments with 1 seta each.

Maxilliped reduced to a small lobe with a little seta (Fig. 15D). $15 \mathrm{~A})$.

Leg 1 resembling that of E. mediana sp.n. (Fig.

Fifth leg (Fig. 15F) resembling that of E. mediana sp.n. but with smaller spinules on outer margin of exopod, and without spinules on inner margin; terminal seta small and naked.

Urosome not ornamented with serrated frills.

Furca, as other species of the genus, 8 times as long as wide.

Etymology. The specific name is derived from the Greek "ali" and "gnathos" which means "reduced" and "mandible" and refers to the very reduced mouthparts of this species.

Remarks. Several other species belonging to Einslepinella gen.n. have been discovered by me in Arctic and Antarctic waters, as well as in the Atlantic deep sea. The genus appears very speciose and widely distributed.

One striking diagnostic apomorphy of the new genus is the absence of an inner coxal seta on the first leg. No other cyclopinid genus has this apomorphy in its groundpattern. In addition, the terminal outer element of the third endopodal segment of leg 2 is a lamellate spine. This is a unique apomorphy within the family, as is the outer lamellate element on the third endopodal segment of leg 3 . It should to be noted, however, that this element is absent in Schminkepinella gen.n., so that it cannot be excluded that this character may represent a synapomorphy of these two genera.

Einslepinella gen.n. is remarkable because of the great variation in maxillipedal morphology, as evidenced by the 3 new species. The shape of the maxilliped reaches from the robust type in E. ulrichi gen.n., sp.n. which has an apical spike-like spine, to the minute foliaceous type in E. alignatha sp.n. The reduction of mouthparts (in particular maxillule and maxilla) together with the falcate mandibular gnathobasis is similar to the condition present in species currently ascribed to the poecilostome families, which are associated with invertebrates and fishes. This suggests that species belonging to Einslepinella gen.n. may be associated with marine invertebrates.

\section{Phylogenetic relationships within Schminkepinellidae fam.n.}

In order to make a detailed analysis of the phylogenetic relationships within Schminkepinellidae fam.n., types of Cyclopinella were examined. In addition 2 new species of this genus from the Atlantic deep sea have been described. These descriptions will be published separately, as will 3 new species of Barathricola Humes, 1999, from Antarctic and Arctic waters. Character states used below for these genera are based on personal observations of this material.

Within the new family, Schminkepinella gen.n. and Einslepinella gen.n. are the most derived genera, and are considered herein as sister groups. Synapomorphies of both genera are the 8-segmented antennule in the female (being 12-segmented in Cyclopinella and 15segmented in Barathricola and Muceddina); the falcate mandibular gnathobasis (in all other genera it is gnathostomous); maxillary endopod with at most 4 setae (while 5 setae are present in Cyclopinella and Barathricola, and 6 setae in Muceddina); and an at most 3-segmented maxillipedal endopod (while it is 4-segmented in Cyclopinella and 5-segmented in Barathricola and Muceddina). 


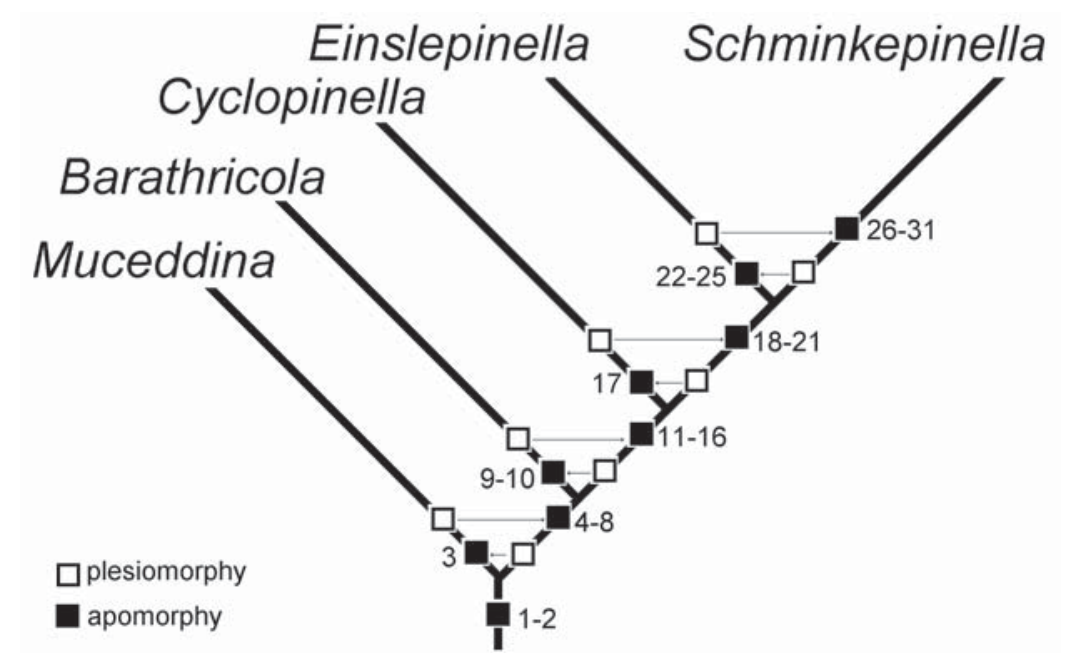

Fig. 16. Phylogenetic relationships within Schminkepinellidae fam.n.

Рис. 16. Филогенетические отношения в Schminkepinellidae fam.n.

Most closely related to these two genera is Cyclopinella. This genus is characterised by a mandibular exopod composed of a single seta, while 1 to 4 exopodal segments with at least 2 setae (altogether) are present in other genera of the family.

Synapomorphic characters of Cyclopinella, Einslepinella gen.n., and Schminkepinella gen.n. include the 1-segmented mandibular endopod (2-segmented in Barathricola and $\mathrm{Mu}$ ceddina); absence of setae representing the maxillulary epipodite ( 2 setae present in Barathricola and 3 setae in Muceddina); a maxillipedal endopod of at most 4-segments (5-segmented in Barathricola and Muceddina); outer seta of the distal endopodal segment of leg 1 transformed into a spine (although this seta is lost in Schminkepinella gen.n.); and finally the loss of furcal seta I (present, albeit reduced in size, in Barathricola and Muceddina).

The sister group of this cluster of 3 genera is the genusBarathricola. This genus is characterised by the absence of armature elements on the first exopodal segment of the mandible, and by a sexually dimorphic terminal outer spine on the third endopodal segment of leg 3 .

Synapomorphies of the cluster of genera comprising Barathricola, Cyclopinella, Einslepinella gen.n. and Schminkepinella gen.n. include absence of a seta on the basis of anten- na (1 seta present in Muceddina); an 3-segmented at most mandibular exopod (4-segmented in Muceddina); at most 2 setae on the maxillulary epipodite (3 setae in Muceddina); at most 5 setae on maxillulary endopod ( 6 setae in Muceddina); and seta III located on the dorsal margin of the furca (located on the terminal outer margin in Muceddina which is the condition present in the groundpattern of Copepoda).

Finally Muceddina, characterised by the presence of 3-4 modified spinules along the inner margin of leg 1 basis, is considered here the first offshot within Schminkepinellidae fam.n.

The new family is characterised by the following apomorphies: absence of a maxillulary coxal endite (an endite with one seta present in ground pattern of other cyclopinid families) and the transformation of the distal inner seta on the middle endopodal segment of leg 4 into a spine (usually lamellate) (this element being a bipinnate seta in the ground pattern of all other cyclopoid families except the Euryteinae).

The phylogenetic relationships of and within Schminkepinellidae fam.n. as discussed herein can be represented graphically in a phylogenetic argumentation scheme (Fig. 16). Apomorphic characters used for this analysis are numbered below (plesiomorphic condition in brackets). 
List of characters:

1) Distal armature element on inner margin of middle segment of leg 4 a spine (a seta).

2) Maxillule without coxal endite (endite present, with one seta).

3) Basis leg 1 with 3-4 modified spinules (spinules not modified)

4) Furcal seta III located on dorsal margin (on lateral margin).

5) Maxillulary endopod with no more than 5 setae (6 setae).

6) Maxillulary epipodite with no more than 2 setae (3 setae).

7) Mandibular exopod with no more than 3 segments (4-segmented).

8) Antennary basis without inner seta (with one inner seta).

9) Outer terminal spine on third endopodal segment of leg 3 sexually dimorphic (not dimorphic).

10) First exopodal segment on mandible asetose (with one seta)

11) Furcal seta I absent (present).

12) Outer element on third endopodal segment of leg 1 a spine (a seta).

13) Maxillipedal endopod with no more than 4 segments (5-segmented).

14) Maxillulary epipodite without setae (with 2 setae).

15) Mandibular endopod 1-segmented (2-segmented)

16) Antennula with no more than 12 segments in female (15-segmented).

17) Mandibulary exopod represented by 1 seta (at least 1 segment present).

18) Maxillipedal endopod with no more than 3 segments (4-segmented).

19) Maxillulary endopod with no more than 4 setae ( 5 setae).

20) Falcate mandible (gnathostomous mandible).

21) Antennule 8-segmented in female (12-segmented).

22) Outer element on third endopodal segment of leg 3 a spine (a seta).

23) Terminal outer element on third endopodal segment of leg 2 a spine (a seta).

24) Maxillulary endopod represented by 2 setae (1 segment with 4 or more setae).

25) Inner coxal seta on leg 1 absent (present).

26) Terminal inner element on third endopodal segment of leg 3 a seta (a spine).

27) Maxillipedal endopod 1-segmented, confluent with feather-like seta (3-segmented or more, no feather-like seta).

28) Mandibular exopod 1-segmented (3-segmented)

29) Second and third antennary endopodal segments fused (not fused).

30) Outer element on third endopodal segments of legs 1-4 absent (present).

31) Outer basal seta of leg 1 absent (present).
Table 1. Character matrix. Таблица 1. Таблица состояния признаков.

\begin{tabular}{|c|c|c|c|c|c|}
\hline & $\begin{array}{l}\text { Muced- } \\
\text { dina }\end{array}$ & $\begin{array}{l}\text { Barath- } \\
\text { ricola }\end{array}$ & $\begin{array}{l}\text { Cyclo- } \\
\text { pinella }\end{array}$ & $\begin{array}{l}\text { Einsle- } \\
\text { pinella }\end{array}$ & $\begin{array}{l}\text { Schminke- } \\
\text { pinella }\end{array}$ \\
\hline 1 & 1 & 1 & 1 & 1 & 1 \\
\hline 2 & 1 & 1 & 1 & 1 & 1 \\
\hline 3 & 1 & 0 & 0 & 0 & 0 \\
\hline 4 & 0 & 1 & 1 & 1 & 1 \\
\hline 5 & 0 & 1 & 1 & 1 & 1 \\
\hline 6 & 0 & 1 & 1 & 1 & 1 \\
\hline 7 & 0 & 1 & 1 & 1 & 1 \\
\hline 8 & 0 & 1 & 1 & 1 & 1 \\
\hline 9 & 0 & 1 & 0 & 0 & 0 \\
\hline 10 & 0 & 1 & $?$ & 0 & 0 \\
\hline 11 & 0 & 0 & 1 & 1 & 1 \\
\hline 12 & 0 & 0 & 1 & 1 & 1 \\
\hline 13 & 0 & 0 & 1 & 1 & 1 \\
\hline 14 & 0 & 0 & 1 & 1 & 1 \\
\hline 15 & 0 & 0 & 1 & 1 & 1 \\
\hline 16 & 0 & 0 & 1 & 1 & 1 \\
\hline 17 & 0 & 0 & 1 & 0 & 0 \\
\hline 18 & 0 & 0 & 0 & 1 & 1 \\
\hline 19 & 0 & 0 & 0 & 1 & 1 \\
\hline 20 & 0 & 0 & 0 & 1 & 1 \\
\hline 21 & 0 & 0 & 0 & 1 & 1 \\
\hline 22 & 0 & 0 & 0 & 1 & $?$ \\
\hline 23 & 0 & 0 & 0 & 1 & 0 \\
\hline 24 & 0 & 0 & 0 & 1 & 0 \\
\hline 25 & 0 & 0 & 0 & 1 & 0 \\
\hline 26 & 0 & 0 & 0 & 0 & 1 \\
\hline 27 & 0 & 0 & 0 & 0 & 1 \\
\hline 28 & 0 & 0 & ? & 0 & 1 \\
\hline 29 & 0 & 0 & 0 & 0 & 1 \\
\hline 30 & 0 & 0 & 0 & 0 & 1 \\
\hline 31 & 0 & 0 & 0 & 0 & 1 \\
\hline
\end{tabular}




\section{Acknowledgements}

This study was supported by the Deutsche Forschungsgemeinschaft. I am very grateful to Prof. Dr. H.K. Schminke for inviting me to participate in ARK-IX/4, and for commenting critically on the manuscript.

\section{References}

Ax P. 1984. Das Phylogenetische System. Stuttgart: Gustav Fischer Verlag. 349 pp.

Hennig W. 1982. Phylogenetische Systematik. Pareys Studientexte, 34. Berlin: Parey Verlag. 246 p.

Humes A.G. 1999. Copepoda (Cyclopinidae and Misophriidae) from a deep-sea hydrothermal vent site in the northeastern Pacific // Journal of Natural History. Vol.33. P.961-978.

Jaume D., Boxshall G.A. 1996. Two new genera of cyclopinid copepods (Crustacea) from anchihaline caves on western Mediterranean and eastern Atlantic is- lands // Zoological Journal of the Linnean Society. Vol.117. P.283-304.

Lang K. 1946. Einige für die schwedische Fauna neue marine Cyclopoida Gnathostoma nebst Bemerkungen über die Systematik der Unterfamilie Cyclopininae // Arkiv för Zoologi. Vol.38. P.1-16.

Lindberg K. 1952. La sous-famille des Cyclopininae Kiefer (Crustacées Copépodes) // Arkiv för Zoologi (B). Vol.4. P.311-325.

Meier R. 1992. Der Einsatz von Computern in phylogenetischen Analysen - eine Übersicht // Zoologischer Anzeiger. Vol.229. No 3/4. P.106-133.

Sars G.O. 1913. Copepoda Cyclopoida. Parts I and II. Oithonidae, Cyclopinidae, Cyclopidae (part). An account of the Crustacea of Norway, 6. P.1-31; pls 1-16.

Schminke H.K. 1976. The ubiquitous telson and the deceptive furca // Crustaceana. Vol.30. P.292-300.

Steuer A. 1940. Über einige Copepoda Cyclopoida der mediterranen Amphioxussande // Note dell'Istituto Italo-Germanico di Biologia Marina di Rovigno D'Istria. Vol.2. No.17. P.1-27.

Willen E. 1996. Pseudomesochra T. Scott, 1902 as a member of the Paranannopidae Por, 1986 (Copepoda, Harpacticoida) with a description of three new species // Senckenbergiana maritima. Vol.28. P.81-109. 